University of Nebraska - Lincoln

DigitalCommons@University of Nebraska - Lincoln

\title{
Phenotypic divergence in two sibling species of shorebird: Common Snipe and Wilson's Snipe (Charadriiformes: Scolopacidae)
}

Tiago M. Rodrigues

Universidade do Porto, Portugal, trodrigues@cibio.up.pt

Edward H. Miller

Memorial University, St. John's, NL, tmiller@mun.ca

Sergei V. Drovetski

Smithsonian Institution, Washington, DC, DrovetskiS@si.edu

Robert M. Zink

University of Nebraska - Lincoln, rzink2@unl.edu

Jon Fjeldså

University of Copenhagen, jfjeldsaa@snm.ku.dk

See next page for additional authors

Follow this and additional works at: https://digitalcommons.unl.edu/bioscifacpub

Part of the Biology Commons, and the Ornithology Commons

Rodrigues, Tiago M.; Miller, Edward H.; Drovetski, Sergei V.; Zink, Robert M.; Fjeldså, Jon; and Gonçalves, David, "Phenotypic divergence in two sibling species of shorebird: Common Snipe and Wilson's Snipe (Charadriiformes: Scolopacidae)" (2020). Faculty Publications in the Biological Sciences. 833.

https://digitalcommons.unl.edu/bioscifacpub/833

This Article is brought to you for free and open access by the Papers in the Biological Sciences at DigitalCommons@University of Nebraska - Lincoln. It has been accepted for inclusion in Faculty Publications in the Biological Sciences by an authorized administrator of DigitalCommons@University of Nebraska - Lincoln. 


\section{Authors}

Tiago M. Rodrigues, Edward H. Miller, Sergei V. Drovetski, Robert M. Zink, Jon Fjeldså, and David Gonçalves 


\title{
Phenotypic divergence in two sibling species of shorebird: Common Snipe and Wilson's Snipe (Charadriformes: Scolopacidae)
}

\author{
TIAGO M. RODRIGUES, ${ }^{1,2 *}$ (D) EDWARD H. MILLER, ${ }^{3}$ (D) SERGEI V. DROVETSKI, ${ }^{4 \dagger}$ \\ ZINK, $^{5}$ (iD JON FJELDSA ${ }^{6}$ iD \& DAVID GONÇALVES ${ }^{1,2}$ \\ ${ }^{1} \mathrm{CIBIO}$, Centro de Investigação em Biodiversidade e Recursos Genéticos, InBIO Laboratório Associado, \\ Universidade do Porto, Campus de Vairão, Rua Padre Armando Quintas, no. 7, Vairão, 4485-661, Portugal \\ ${ }^{2}$ Departamento de Biologia, Faculdade de Ciências, Universidade do Porto, Rua do Campo Alegre s/ $n$, Porto, \\ 4169-007, Portugal \\ ${ }^{3}$ Department of Biology, Memorial University, St. John's, NL, A1B 3X9, Canada \\ ${ }^{4}$ Department of Vertebrate Zoology, National Museum of Natural History, Smithsonian Institution, Washington, DC, \\ 20004, USA \\ ${ }^{5}$ School of Natural Resources, School of Biological Sciences, Nebraska State Museum, Lincoln, NE, 68583, USA \\ ${ }^{6}$ Center for Macroecology, Evolution and Climate, Natural History Museum of Denmark, University of Copenhagen, \\ Copenhagen, Denmark
}

\begin{abstract}
Natural and social selection are among the main shapers of biological diversity but their relative importance in divergence remains understudied. Additionally, although neutral evolutionary processes may promote phenotypic divergence, their potential contribution in speciation is often overlooked in studies of comparative morphology. In this study, we investigated phenotypic differentiation in two allopatric shorebirds: the Palaearctic Common Snipe Gallinago gallinago and the Nearctic Wilson's Snipe Gallinago delicata. Specimens of Common Snipe ( $n=355$ skins, $n=163$ skeletons) and Wilson's Snipe $(n=403$ skins, $n=141$ skeletons) in natural history collections were examined to quantify differences in skeletal and external measurements, and measures of wing and tail plumage variables. The species do not differ in skeletal variables except for the relatively larger sternum of the Common Snipe. The two species do not differ in multivariate wing size or shape (pointedness). Previously known plumage differences between these species were confirmed: the Common Snipe has fewer rectrices, longer and wider outermost rectrices, more extensive white on tips of the secondary feathers, and more white in the axillaries. Between-species variance in skeleton, primary length and plumage variables was greater than expected if drift was mainly responsible for phenotypic divergence, suggesting a role of selective processes. However, drift could not be rejected after adjusting for multiple comparisons. Differences in plumage traits were greater than in skeletal or external measurements. Because snipe use plumage traits in signalling, the results suggest a more rapid divergence in socially selected traits between these species than in traits related to resource use.
\end{abstract}

Keywords: Gallinago delicata, Gallinago gallinago, genetic drift, museum collections, natural selection, social selection, speciation.

\footnotetext{
${ }^{\dagger}$ Present address: USGS Patuxent Wildlife Research Center, 10300 Baltimore Avenue, BARC-East Bldg. 308, Beltsville, MD, 20705, USA.

*Corresponding author. Email: trodrigues@cibio.up.pt Twitter: @TiagoMRodrigues
}

More than a decade after the publication of his explanation for the evolutionary role of natural selection (Darwin 1859), Darwin devoted an entire book to another mechanism that, along with natural selection, also contributes to descent with 
modification. In The Descent of Man and Selection in Relation to Sex, Darwin (1871) developed a concept that he had introduced briefly in The Origin (Darwin 1859; pp. 87-90): sexual selection, a mechanism that depends on the advantage that certain individuals have over other individuals of the same sex and species, in exclusive relation to reproduction' (Darwin 1871; p. 256). Sexual selection was later included under the umbrella of social selection (West-Eberhard 1983), a concept that accommodates selection on traits that function in many kinds of intraspecific social interactions (West-Eberhard 1983, 2014, Price 2008, Lyon \& Montgomerie 2012, Tobias et al. 2012, McEntee et al. 2016). The relative contributions of natural and social selection as drivers of biological diversity merit further study (West-Eberhard 1983, 2014, Price 2008, Lyon \& Montgomerie 2012, Tobias et al. 2012, McEntee et al. 2016, Littleford-Colquhoun et al. 2019).

In early stages of divergence, when allopatric populations face similar ecological conditions, social selection can be an important cause of morphological change over time (Winger \& Bates 2015) because niche conservatism can impede divergence in traits related to resource use (Wiens et al. 2010, Zink 2014). The relative importance of natural and social selection can be evaluated with a trait-based approach (Safran et al. 2013) by quantifying divergence in traits with probable primary signalling functions and comparing this with divergence in traits more related to resource use. Many sister taxa and allopatric populations differ primarily in display traits related to mate choice and species recognition, so social selection may be the main cause of divergence, particularly in early stages of differentiation (Panhuis et al. 2001, Seddon et al. 2013). An example of early divergence is afforded by the Barn Swallow Hirundo rustica, in which populations with low genetic differentiation show significant phenotypic differentiation in signalling characters but not in ecological traits (Wilkins et al. 2016). Socially selected characters also diverged more rapidly than ecologically relevant traits in Junco (Friis \& Milá 2020).

Natural and sexual selection also play roles in the evolution of differences between the sexes (Darwin 1859, 1871) but disentangling their relative contributions to the evolution of sexual differences in vocalizations, colour or body size is challenging (Littleford-Colquhoun et al. 2019, Price 2019). Among birds, the evolution of sexual- size dimorphism (SSD) seems to be a result of intrasexual competition (Székely et al. 2000, 2004, 2007, Drovetski et al. 2006, Trefry \& Diamond 2017). For most species, this led males, the more competitive sex, to become larger than females; however, several taxa evolved in the opposite direction (Székely et al. 2007). Among scolopacids, the evolution of reversed SSD seems to be associated with the demands of males' aerial courtship displays (Székely et al. 2000, 2004, 2007), as smaller bodies may be advantageous in flight agility (Trefry \& Diamond 2017). However, differences in foraging ecology, parental roles or even the needs imposed by egg production may also explain patterns of SSD (Székely et al. 2007).

Phenotypic divergence also may be promoted by neutral evolutionary processes, such as drift (Mayr 1954, Lande 1976, 1980) but because their roles in the evolution of phenotypic traits and behavioural isolation seem minor (Coyne et al. 1997, Coyne \& Orr 2004, Price 2008), their potential contribution in speciation is seldom tested in comparative studies. Drift alone could not explain phenotypic differentiation across populations of House Sparrow Passer domesticus (Holand et al. 2011, Geue et al. 2016, Cohen \& Dor 2018, but see Kekkonen et al. 2012) but could not be rejected in other studies, suggesting an occasional role for neutral processes in trait divergence unrelated to resource use or mate choice and species recognition. For instance, neutral processes seem to have been important in the variation of bill length of Berthelot's Pipit Anthus berthelotii among Atlantic islands (Spurgin et al. 2014, Armstrong et al. 2018) and were the main drivers of geographical variation in plumage colour of the Eastern Yellow Robin Eopsaltria australis at the continental scale (Morales et al. 2017). These results emphasize the need to test this hypothesis in studies of phenotypic divergence before assuming that the patterns under study arise solely from selective pressures.

Snipes (Gallinago spp.) are shorebirds, with cryptic plumage and specialized long and flexible bills that they use to probe the soil. The 17 extant species of snipe (Gill \& Donsker 2019) exhibit limited plumage differences across species, except in the tail (Tuck 1972), which is a striking component of their ground and aerial displays (Sutton 1981, Cramp \& Simmons 1983, Glutz von Blotzheim et al., 1986). In addition, with the exception of the Great Snipe Gallinago gallinago, which lacks 
an aerial display, the rectrices are responsible for the species-specific instrumental sound that is audible during flight displays (van Casteren et al. 2010, Clark \& Prum 2015). Other aspects of snipe communication are poorly known but include display of the underwing (Sutton 1981, Cramp \& Simmons 1983, Glutz von Blotzheim et al. 1986).

This study investigates phenotypic divergence between the closely related Common Snipe G. gallinago and Wilson's Snipe Gallinago delicata (Fig. 1). The Common Snipe is sympatric with at least four other snipe species across its Palaearctic breeding range, whereas Wilson's Snipe is the only Gallinago species that regularly breeds in North America. Slight mitochondrial DNA (mtDNA) differentiation between them suggests ongoing or recent speciation (Zink et al. 1995, Baker et al. 2009, Kerr et al. 2009, Johnsen et al. 2010). Fossils of the Common Snipe from the Palaearctic are known from the Early Pleistocene (Mlíkovský 2002). In North America, remains that represent Common Snipe or Wilson's Snipe also are known from the Pleistocene (Bordkorb 1967, Stock \& Harris 1992) and have been identified at Rancho La Brea (Stock \& Harris 1992) and at a site in Tennessee (Parmalee \& Klippel 1982).

Phenotypic variation between Common Snipe and Wilson's Snipe was analysed in traits that probably are of little communicative significance (e.g. body size), others that may be used in optical signalling (e.g. traits of body plumage) and others that are known or likely to be important in communication (e.g. number and size of rectrices), using museum specimens of skeletons and study skins. The null hypothesis of neutral evolution was tested to investigate whether selection could be responsible for the differences observed. If drift was the main process responsible for the divergence, phenotypic variation within species should be proportional to that between species (Lande 1976, 1980, Lofsvold 1988, Ackermann \& Cheverud 2002, 2004). The phenotypic distances between species were then evaluated to infer whether social selection could be responsible for the observed patterns.

\section{METHODS}

\section{Sampling}

Skeletons of fully grown Common Snipe $(n=163)$ and Wilson's Snipe $(n=141)$, and study skins of adult (after the first post-breeding moult) Common Snipe $(n=355)$ and Wilson's Snipe $(n=403)$ in 23 collections (Fig. 1; Acknowledgements and Table S1) were measured. Data on sex and age were taken from specimen tags or collection catalogues. Additionally, age classes of study skins were determined based on patterns of wing coverts and rectrices (Czajkowski 2002, Pyle 2008). Specimens analysed for this study are listed in Table S1.

\section{Data collection}

To quantify phenotypic variation in skeleton morphology, 16 skeletal variables were measured (Fig. 2a; terminology follows Baumel \& Witmer 1993): (1) Cranium, cranial length, from distal end of rostrum maxillare to prominentia cerebellaris; (2) Premaxilla, length of premaxilla, from distal end of rostrum maxillare to ginglymus craniofacialis (frontonasal suture); (3) Sternal length, length of sternum, from anteriormost point on spina externa to posteriormost point on margo caudalis; (4) Keel length, length of sternal keel, from anteriormost point on apex carinae to posteriormost point on margo caudalis; (5) Keel depth, depth of sternum, perpendicular to length of sternal keel (along pila carinae), from dorsalmost point on spina externa to margo ventralis; (6) Coracoid, maximal length of coracoid, processus acrocoracoideus to distal point of the facies articularis intercoiracoidea; (7) Humerus, maximal length of humerus, caput humeri to condylus ventralis; (8) Radius, maximal length of radius, cotyla humeralis to facies articularis radiocarpalis; (9) Ulna, maximal length of the ulna, olecranon to condylus ventralis; (10) Carpometacarpus, maximal length of carpometacarpus, from trochlea carpalis to facies articularis digitalis major; (11) Phalanx 1, maximal length of phalanx proximalis digit majoris (along pila cranialis phalangis); (12) Ischial length, maximal length of the ischium, from margo iliocranialis to processus terminalis ischii; (13) Ischial depth, ischial depth, corpus ischii to crista dorsolateralis; (14) Femur, maximal length of the femur, trochanter femoris to condylus lateralis; (15) Tibiotarsus, maximal length of the tibiotarsus, crista cnemialis cranialis to condylus lateralis; (16) Tarsometatarsus, maximal length of the tarsometatarsus, eminentia intercotylaris to trochlea metatarsi III. Lengths of cranium and premaxilla were used to estimate length of the braincase (Braincase $=$ Cranium - 

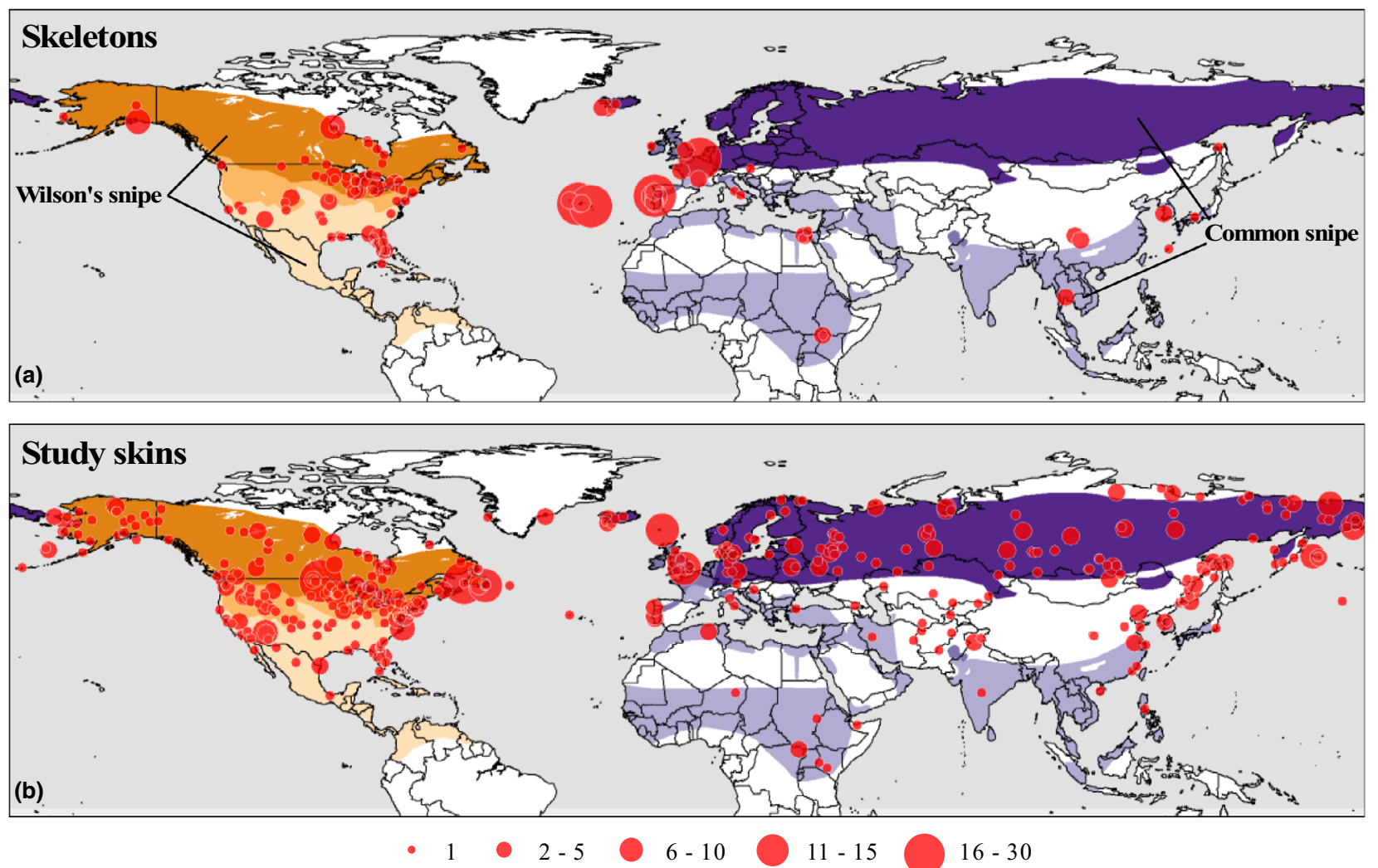

Figure 1. Geographical samples of (a) skeletons and (b) study skins of Common Snipe Gallinago gallinago and Wilson's Snipe Gallinago delicata analysed in this study. The area of the circles indicates relative sample size. The darker, intermediate and lighter shaded areas indicate, respectively, the breeding, year-round and wintering ranges of the Common Snipe (eastern hemisphere) and Wilson's Snipe (western hemisphere) (adapted from BirdLife International \& NatureServe 2015).

Premaxilla; here and below, variable names are italicized and in capitals). Measurements were made with a digital calliper to $\pm 0.1 \mathrm{~mm}$. In a few cases, broken bones were reassembled with the help of modelling clay for measurement. Distorted bones (e.g. due to healed injuries) were not measured. Left-side measurements were used when possible for consistency, although right-side measurements were used if left-hand elements were damaged or missing.

Phenotypic variation in morphology was also quantified from four external body size-related variables (hereafter 'external variables') measured on study skins: Bill, length of the bill from its tip to the dorsal swelling at its posterior end, on the midline; Tarsus, length of the tarsus from the back of the intertarsal joint to the distal front edge of the last complete scale before the toes diverge; Tail, length of the tail, from the insertion of the central pair of rectrices to the tip of the longest (central) rectrix; and Wing, length of flattened wing, from the carpal joint to the tip of the longest primary (Eck et al. 2011). Bill and Tarsus were measured with digital callipers to $\pm 0.1 \mathrm{~mm}$. Tail and Wing were measured with a ruler to $\pm 1 \mathrm{~mm}$. Additionally, to assess variation in wing morphology, the distances between the tips of the longest primary and all other primaries were measured along the flattened wing with digital callipers to $\pm 0.1 \mathrm{~mm}$. Primary lengths $(P 1-P 10)$ were then calculated by subtracting those distances from Wing (Evered 1990).

To evaluate phenotypic variation in plumage, five non-primary plumage variables were quantified (hereafter 'plumage variables'): White in the secondaries, mean value of the depth of the white portion on the tip of each secondary feather (on the right wing), measured along the shaft in the inner web of the feather with a digital calliper to $\pm 0.1 \mathrm{~mm}$ (Fig. 2b); Outer rectrix vane length, 

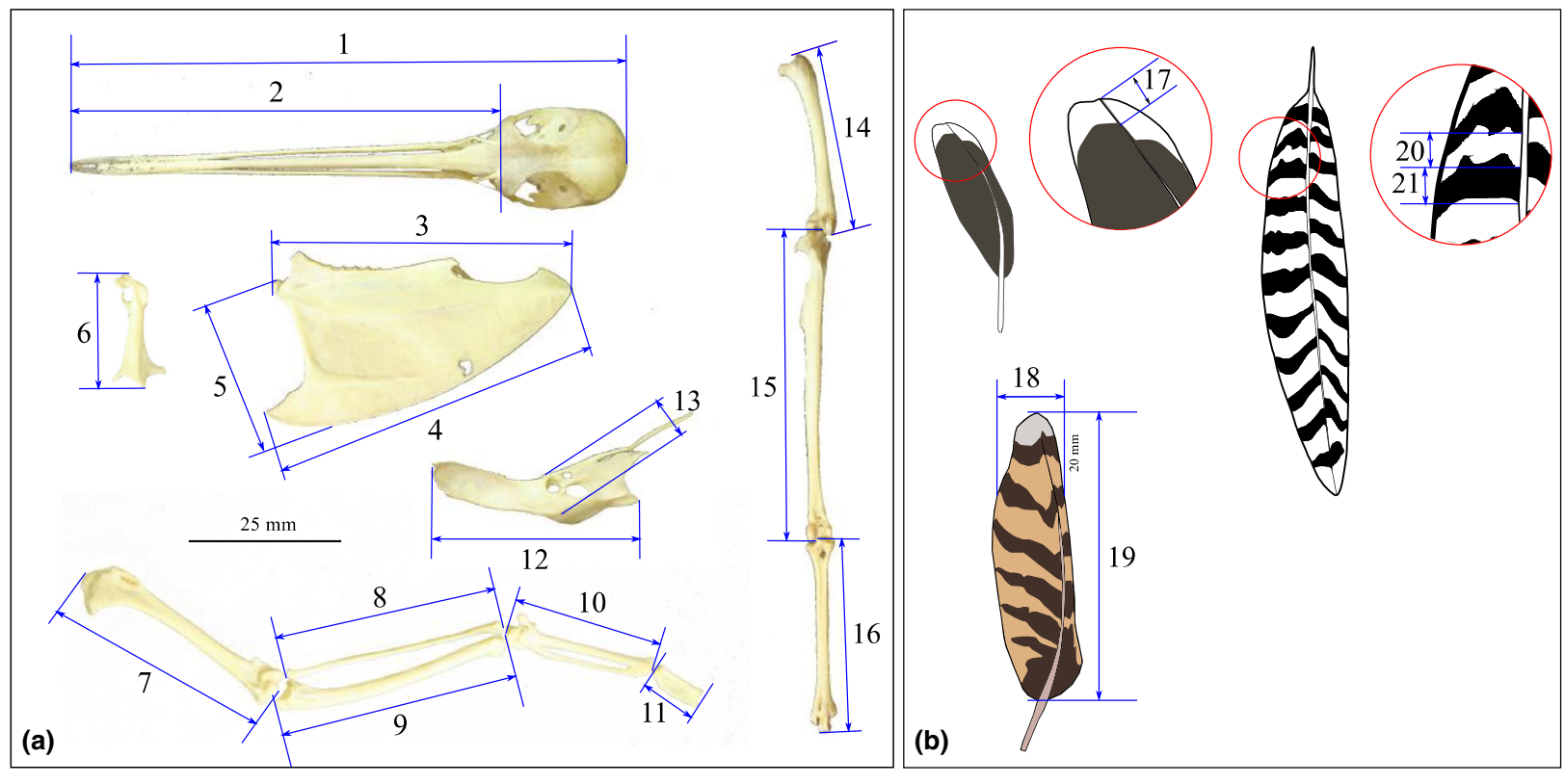

Figure 2. (a) Variables measured on skeletons (see text for descriptions): (1) Cranium, (2) Premaxilla, (3) Sternal length, (4) Keel length, (5) Keel depth, (6) Coracoid, (7) Humerus, (8) Radius, (9) Ulna, (10) Carpometacarpus, (11) Phalanx 1, (12) Ischial length, (13) Ischial depth, (14) Femur, (15) Tibiotarsus and (16) Tarsometatarsus. (b) Variables measured on plumage: (17) White in the secondaries, (18) Outer rectrix vane width and (19) Outer rectrix vane length; $(20,21)$ projection of white and dark markings along the axillary's shaft, respectively, used to calculate the variable White in the axillaries.

length of the vane of the outermost rectrix (preferably the left) measured with a ruler to $\pm 1 \mathrm{~mm}$; Outer rectrix vane width, width of the vane of the outermost rectrix (preferably the left) measured with a ruler to $\pm 0.5 \mathrm{~mm}$ at $20 \mathrm{~mm}$ from its distal tip (Fig. 2b); Number of rectrices, the number of rectrices on specimens with at least one half of the rectrices present (any signs of moulting or missing rectrices were recorded; when rectrices were missing on one side, the total number of rectrices was inferred assuming tail symmetry); and White in the axillaries, proportion of white on the axillaries, dividing the sum of the extent of white by the sum of white and dark markings, the projection of each dark and white marking on the longest axillary measured with a digital calliper to $\pm 0.1 \mathrm{~mm}$ (Fig. 2b).

\section{Measurement repeatability}

The first author made all measurements. Subsamples of 30 skeletons and 30 study skins of Common Snipe and Wilson's Snipe were measured three times, in random order, to quantify measurement error (ME). The R package ICC (Wolak et al. 2012) was used to estimate repeatability expressed as the intraclass correlation coefficient (ICC) and percentage of measurement error (\% ME) computed as (1 - ICC) × 100 (Table S2).

\section{Statistical analyses}

All variables were $\ln$-transformed before analyses. Patterns of phenotypic variation in skeletal, external, wing and plumage traits were investigated through principal components analyses (PCAs) and included 15 skeletal variables, the four external variables, the lengths of the 10 primaries and five plumage variables, respectively. PCAs (non-rotated) based on correlation matrices were performed using the 'princomp' function of the $\mathrm{R}$ stats package (version 3.6.1; R Core Team 2019). The Kaiser criterion (Kaiser 1960) and the scree test (Cattell 1966) were used to decide the number of components to retain. Differences between species on these components were tested with non-parametric analyses of variance, with 1000 permutations, including sex, species and their interaction as independent variables in the $\mathrm{R}$ package $1 \mathrm{mPerm}$ (Wheeler \& Torchiano 2016). 
To test whether selection could be responsible for phenotypic differences between species, in skeletons, skins, wings and plumage, the beta-test of Ackermann and Cheverud (2002), which assumes that genetic drift is the only process responsible for differences between species, was used to attempt to reject the null hypothesis of neutral evolution (Lande 1976, 1979). Accordingly, if phenotypic disparity between Common Snipe and Wilson's Snipe results from neutral evolutionary processes, the between-species variance $(B)$ should be proportional to the withinspecies variance $(W$; Ackermann \& Cheverud 2002). R code in Mutumi et al. (2017) was used to determine $B$ and $W$ for each partition. First, the residuals variance-covariance (VCV) matrices of non-parametric multivariate analyses of variance, with 1000 permutations, including sex and species as independent variables, were computed to remove variation explained by differences between sexes and species (Mutumi et al. 2017). PCAs were performed with each residual VCV matrix, and the eigenvalues were extracted to represent $W$ (Cornuault et al. 2015, Mutumi et al. 2017). The last PC of each PCA was not considered due to low explained variance (Table S3). The matrices of the eigenvectors were multiplied by the respective matrices of the trait means for each species, and the variances associated with each column of the new matrices were calculated to represent $B$ (Mutumi et al. 2017). Finally, the proportionality between $B$ and $W$ was evaluated by regressing $\ln (B)$ over $\ln (W)$; slopes of 1 indicate that drift was the diversifying source, whereas significant deviations from this value suggest that this process was probably not responsible for the observed pattern (Ackermann \& Cheverud 2002).

Phenotypic distances between the Common Snipe and Wilson's Snipe were determined with a non-parametric distance measure, $\Delta p$ (Safran et al. 2012). Distances were measured in terms of the percentiles at which the median of each population lies on a joint cumulative distribution function. In comparison with other metrics, $\Delta p$ is relatively insensitive to unequal variances and sample sizes among populations (Safran et al. 2012).

All analyses were performed in R 3.6.1 (R Core Team 2019) or MATLAB R2017b (The MathWorks, Inc., Natick, MA, USA) and results were considered to be significant at $P<0.05$. Sidák's correction (Šidák 1967) was computed to adjust $P$-values for multiple comparisons.

\section{RESULTS}

\section{Phenotypic variation}

The first two axes of the PCA of the skeletal variables accounted for 51 and $11 \%$ of the variance, respectively (Table 1). All 15 traits loaded positively and significantly on $\mathrm{PCl}\left(r_{\mathrm{s}}=0.32-0.89\right.$; all $P<0.001$; Table 1), which mainly represented variation in body size. The birds with relatively larger bodies had higher scores on PCl. Traits with the greatest contribution to PC2 were Keel length, Sternum and Keel depth $\left(r_{\mathrm{s}}=0.78,0.71\right.$ and 0.42, respectively; all $P<0.001$; Table 1), indicating that PC2 primarily represented variation in sternal size. Birds with a relatively larger sternum had higher PC2 scores. Results of a non-parametric analysis of variance (ANOVA) showed that sex but not species or sex-species interaction had a significant effect on $\mathrm{PCl}$ scores (Table 2), indicating that females had larger skeletons than males in both species (Fig. 3a). Both species and sex, but not species-sex interaction (Table 2), had significant effects on PC2 scores. The Common Snipe had a larger sternum compared with Wilson's Snipe, and males had a larger sternum than females in both species (Table 3).

The first two axes of the PCA using the four external variables accounted for 48 and $25 \%$ of the variance, respectively (Table 1). The four variables had significant positive loadings on $\mathrm{PCl}$ $\left(r_{\mathrm{s}}=0.48-0.80 ;\right.$ all $P<0.001 ;$ Table 1$)$, which mostly represented variation in body size. Again, larger birds had higher PCl scores. PC2 was mostly affected by Tail and Tarsus $\left(r_{\mathrm{s}}=-0.79\right.$ and 0.51 , respectively; $P<0.001$; Table 1). The loadings for Wing and Bill $\left(r_{\mathrm{s}}=-0.27\right.$ and 0.25, respectively, $P<0.001$; Table 1) were substantially lower. Birds with relatively shorter tails and longer tarsi had higher PC2 scores. A non-parametric ANOVA of PCl scores (Table 2) indicated that Common Snipe were larger than Wilson's Snipe and females were larger than males (Fig. 3b); the species-sex interaction had no significant effect on $\mathrm{PCl}$ scores. Species and sex, but not the species-sex interaction, had a significant effect on PC2 scores (Table 2). The Common Snipe had a proportionally longer tail but a shorter tarsus compared with Wilson's Snipe (Fig. 3b, 
Table 1. Component loadings (correlations), eigenvalues and percentage of the variance explained by the first two components from principal components analyses (PCAs) on In-transformed skeletal and external variables, primary lengths and plumage variables of Common Snipe Gallinago gallinago and Wilson's Snipe Gallinago delicata. Correlations that were significant at $\alpha=0.05$ are shown in bold type.

\begin{tabular}{|c|c|c|}
\hline & $\mathrm{PC} 1$ & PC2 \\
\hline \multicolumn{3}{|l|}{ Skeletal variables } \\
\hline Premaxilla & $0.586 * * *$ & 0.140 \\
\hline Braincase & $0.319 * * *$ & $0.313^{* * *}$ \\
\hline Sternum & $0.621 * * *$ & $0.705^{* * *}$ \\
\hline Keel length & $0.479 * * *$ & $0.776 * * *$ \\
\hline Keel depth & $0.634 * * *$ & $0.417^{* * *}$ \\
\hline Coracoid & $0.747 * * *$ & -0.126 \\
\hline Humerus & $0.886 * * *$ & $-0.185^{*}$ \\
\hline Radius & $0.879 * * *$ & $-0.179 *$ \\
\hline Carpometacarpus & $0.870 * * *$ & -0.119 \\
\hline Phalanx 1 & $0.684 * * *$ & $-0.168 *$ \\
\hline Ischial length & $0.737 * * *$ & -0.100 \\
\hline Ischial depth & $0.516 * * *$ & -0.100 \\
\hline Femur & $0.847 * * *$ & $-0.236 * *$ \\
\hline Tibiotarsus & $0.835 * * *$ & $-0.195 *$ \\
\hline Tarsometatarsus & $0.811 * * *$ & $-0.165^{*}$ \\
\hline Eigenvalue & 7.684 & 1.656 \\
\hline$\%$ variance & 51.224 & 11.0 \\
\hline \multicolumn{3}{|l|}{ External variables } \\
\hline Bill & $0.799 * * *$ & $0.247 * * *$ \\
\hline Tarsus & $0.734 * * *$ & $0.509 * * *$ \\
\hline Tail & $0.479 * * *$ & $-0.787 * * *$ \\
\hline Wing & $0.723 * * *$ & $-0.268 * * *$ \\
\hline Eigenvalue & 1.930 & 1.012 \\
\hline$\%$ variance & 48.259 & 25.288 \\
\hline \multicolumn{3}{|l|}{ Primary lengths } \\
\hline P10 & $0.914 * * *$ & $0.329 * * *$ \\
\hline P9 & $0.943 * * *$ & $0.293 * * *$ \\
\hline P8 & $0.961 * * *$ & $0.220 * * *$ \\
\hline P7 & $0.962 * * *$ & $0.177^{* *}$ \\
\hline P6 & $0.971 * * *$ & 0.071 \\
\hline P5 & $0.976 * * *$ & -0.040 \\
\hline $\mathrm{P} 4$ & $0.964 * * *$ & $-0.142 *$ \\
\hline P3 & $0.950 * * *$ & $-0.243^{* * *}$ \\
\hline $\mathrm{P} 2$ & $0.928 * * *$ & $-0.321 * * *$ \\
\hline P1 & $0.876 * * *$ & $-0.369 * * *$ \\
\hline Eigenvalue & 8.928 & 0.599 \\
\hline$\%$ variance & 89.284 & 5.991 \\
\hline \multicolumn{3}{|l|}{ Plumage variables } \\
\hline Outer rectrix vane length & $0.771 * * *$ & $0.431 * * *$ \\
\hline Outer rectrix vane width & $0.880 * * *$ & -0.029 \\
\hline White in the secondaries & $0.903 * * *$ & 0.037 \\
\hline White in the axillaries & $0.875 * * *$ & 0.115 \\
\hline Number of rectrices & $-0.754 * * *$ & $0.586 * * *$ \\
\hline Eigenvalue & 3.518 & 0.544 \\
\hline$\%$ variance & 70.355 & 10.887 \\
\hline
\end{tabular}

The first components (PC1) of PCAs for skeletal and external variables were interpreted as axes of multivariate body size, and the second components (PC2) as body shape. Both components of the PCA on primary lengths explained variations in wing size (PC1) and pointedness (PC2). Most variation in plumage variables was explained by the first components (PC1). Asterisks indicate the significance of each correlation. Primaries are numbered from body toward the wing tip. $* P<0.05$. $* * P<0.01$. $* * * P<0.001$.
Table 3). Females had a relatively shorter tail and a longer tarsus than males (Fig. 3b, Table 3).

In the PCA on primary lengths, the first two axes explained 89 and $6 \%$ of the variance, respectively (Table 1). The 10 primaries had significant positive loadings on PCl $\left(r_{\mathrm{s}}=0.88-0.98\right.$; all $P<0.001$; Table 1), which represented variation in wing size: birds with larger wings had higher $\mathrm{PCl}$ scores. The four distal primaries $(P 7-P 10)$ were positively correlated with PC2 $\left(r_{\mathrm{s}}=0.18\right.$ 0.33 ; all $P<0.01$; Table 1), whereas the four proximal primaries $(P 1-P 4)$ had significant negative loadings $\left(r_{\mathrm{s}}=-0.37\right.$ to -0.31 ; all $P<0.05$; Table 1). Loadings increased outwards (Table 1), denoting variation in wing pointedness. Non-parametric ANOVA of PCl and PC2 scores (Table 2) showed that females had larger wings with a less pointed wingtip (Fig. 3c). Neither species nor species-sex interaction had significant effects on $\mathrm{PCl}$ or PC2 scores (Table 2).

The first two axes of the PCA with the five plumage variables explained 70 and $11 \%$ of the variance, respectively (Table 1). The five variables were highly correlated with $\mathrm{PCl}$, but whereas the correlations of the white in the secondaries, white in the axillaries, length of the outer rectrices and width of the outer rectrices were positive $\left(r_{\mathrm{s}}=0.77-0.90\right.$; all $P<0.001$; Table 1$)$, correlation with the number of rectrices was negative $\left(r_{\mathrm{s}}=-0.75 ; P<0.001 ;\right.$ Table 1$)$. Birds with few rectrices, but with larger outermost rectrices, and more white in the secondaries and axillaries, had higher $\mathrm{PCl}$ scores. Only the number of rectrices and the length of the outermost rectrices correlated significantly with PC2 $\left(r_{\mathrm{s}}=0.59\right.$ and 0.43 , respectively; all $P<0.001$; Table 1 ). Birds with more rectrices and relatively longer outermost rectrices had higher loadings on PC2. The non-parametric ANOVA of $\mathrm{PCl}$ scores revealed a significant effect of sex and species, but not their interaction (Table 2); however, the effects were disparate, as the $F$-value for species was 67 times greater than the $F$-value for sex. The Common Snipe had more white in the axillaries, broader white edges of the secondaries, and broader and longer vanes of the outer rectrices, but fewer rectrices (Fig. 3d, Table 3). Only sex had a significant effect on PC2 scores (Table 2), suggesting that PC2 is primarily related to sexual dimorphism in the variation of signalling characters. Males of both species had relatively more rectrices, and the outermost ones were relatively longer. 
Table 2. Results of permutational two-way crossed designs ANOVA with TAXON and SEX as factors and computed principal components as variables. $P$-values and differences that were significant at $\alpha=0.05$ are shown in bold type.

\begin{tabular}{|c|c|c|c|c|c|c|c|c|c|}
\hline \multirow[b]{2}{*}{ Skeletal variables } & \multirow[b]{2}{*}{ df } & \multicolumn{4}{|c|}{ PC1 ('body size') } & \multicolumn{4}{|c|}{ PC2 ('sternal size’) } \\
\hline & & SS & $F$ & $P$ & diff. & SS & $F$ & $P$ & diff. \\
\hline TAXON & 1 & 1.0 & 0.24 & 0.624 & -0.58 & 81.0 & 37.01 & $<0.001$ & 1.49 \\
\hline SEX & 1 & 1623.0 & 32.82 & $<0.001$ & -6.57 & 10.0 & 4.59 & 0.033 & 0.51 \\
\hline SEX $\times$ TAXON & 1 & 17.0 & 0.35 & 0.557 & & 0.3 & 0.15 & 0.699 & \\
\hline \multirow[t]{2}{*}{ Residuals } & 146 & 7220.0 & & & & 319.4 & & & \\
\hline & & \multicolumn{4}{|c|}{ PC1 ('body size') } & \multicolumn{4}{|c|}{ PC2 ('body shape') } \\
\hline External variables & df & SS & $F$ & $P$ & diff. & SS & $F$ & $P$ & diff. \\
\hline TAXON & 1 & 59.80 & 17.96 & $<0.001$ & 1.89 & 8.95 & 10.34 & $<0.001$ & -0.41 \\
\hline SEX & 1 & 88.20 & 26.49 & $<0.001$ & -1.05 & 15.07 & 17.42 & $<0.001$ & -0.52 \\
\hline SEX $\times$ TAXON & 1 & 12.70 & 3.83 & 0.051 & & 0.14 & 0.16 & 0.687 & \\
\hline \multirow[t]{2}{*}{ Residuals } & 291 & 968.60 & & & & 251.67 & & & \\
\hline & & \multicolumn{4}{|c|}{ PC1 ('wing size’) } & \multicolumn{4}{|c|}{ PC2 ('wing pointedness') } \\
\hline Primary lengths & df & SS & $F$ & $P$ & diff. & SS & $F$ & $P$ & diff. \\
\hline TAXON & 1 & 55.00 & 0.72 & 0.397 & 1.17 & 0.44 & 1.33 & 0.250 & 0.10 \\
\hline SEX & 1 & 899.00 & 11.85 & $<0.001$ & -4.43 & 5.90 & 17.77 & $<0.001$ & 0.34 \\
\hline SEX $\times$ TAXON & 1 & 23.00 & 0.30 & 0.584 & & 0.01 & 0.04 & 0.839 & \\
\hline \multirow[t]{2}{*}{ Residuals } & 227 & 17234.00 & & & & 75.36 & & & \\
\hline & & \multicolumn{4}{|l|}{$\mathrm{PC} 1$} & \multicolumn{4}{|l|}{ PC2 } \\
\hline Plumage variables & df & SS & $F$ & $P$ & diff. & SS & $F$ & $P$ & diff. \\
\hline TAXON & 1 & 1282.70 & 1422.21 & $<0.001$ & 5.59 & 0.60 & 1.21 & 0.271 & -0.10 \\
\hline SEX & 1 & 20.00 & 22.14 & $<0.001$ & 0.67 & 4.81 & 9.68 & 0.002 & 0.29 \\
\hline SEX $\times$ TAXON & 1 & 0.10 & 0.10 & 0.753 & & 0.44 & 0.89 & 0.347 & \\
\hline Residuals & 220 & 198.40 & & & & 109.34 & & & \\
\hline
\end{tabular}

The Common Snipe Gallinago gallinago and Wilson's Snipe Gallinago delicata differ on skeletal and external body-size-related and non-primary plumage variables. Apart from one sternal variable, differences in body size were only manifest externally, and wing size and pointedness did not differ. Sexes differ on size and shape of the body and the wing, and on non-primary plumage variables. df, degrees of freedom; F: pseudo-F-values; $P$ : $P$-value after 1000 permutations; SS, explained sum of squares; diff., differences (Tukey HSD) males - females and Common Snipe - Wilson's Snipe.

\section{Selection}

The regression slopes of between- vs. within-species phenotypic variance differed significantly from 1 for skeletal variables (Fig. 4a), primary lengths (Fig. 4c) and plumage variables (Fig. 4d) but not for external variables (Fig. 4b). In the last, the small number of data points might explain the lack of significance. However, for the other three, after adjusting for multiple comparisons, the null hypothesis could not be rejected at $\alpha=0.05$.

\section{Phenotypic distance}

Despite some significant differences between species on skeletal and external variables, the phenotypic distance analyses $(\Delta p)$ indicated that the largest species differences occurred in plumage variables (Fig. 5a). Furthermore, with the exception of PC2 for skeletal variables (i.e. sternal size), $\Delta p$ for $\mathrm{PCl}$ of plumage variables was greater than for any of the other principal components computed (Fig. 5a). For each sex, $\Delta p$ was similar across 


\section{Skeletal variables}
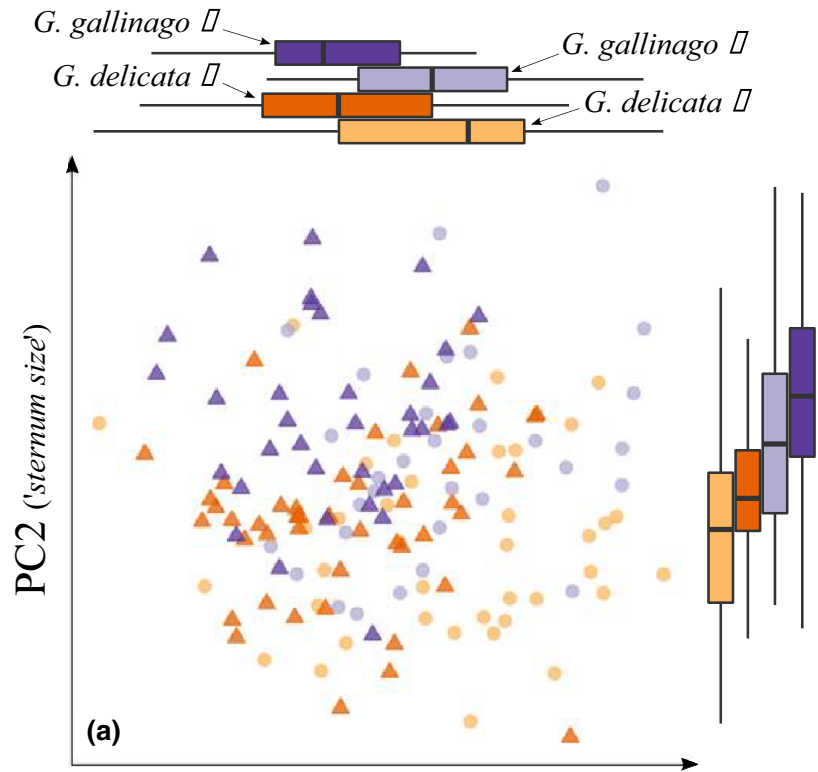

PC1 ('body size')

\section{Primary lengths}

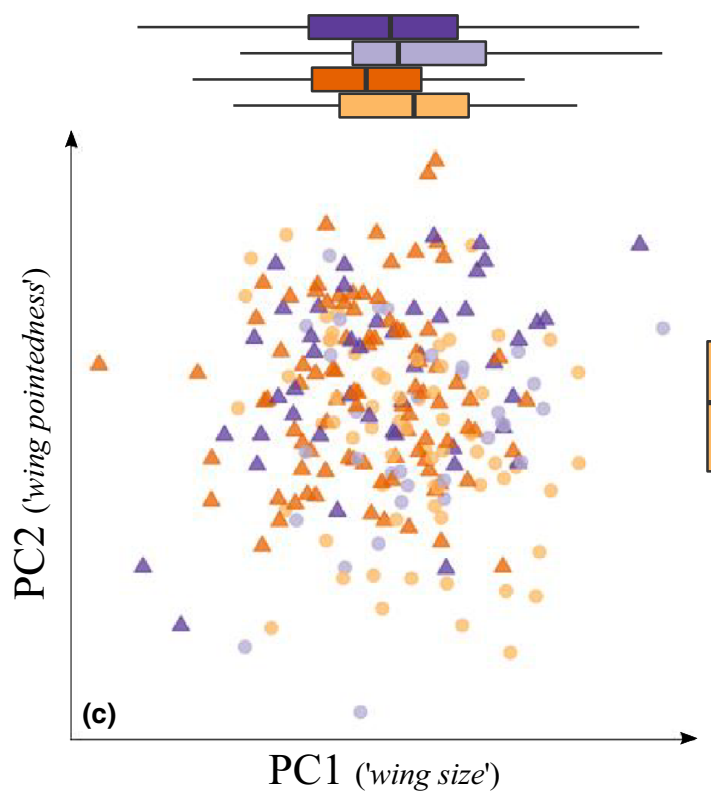

\section{External variables}

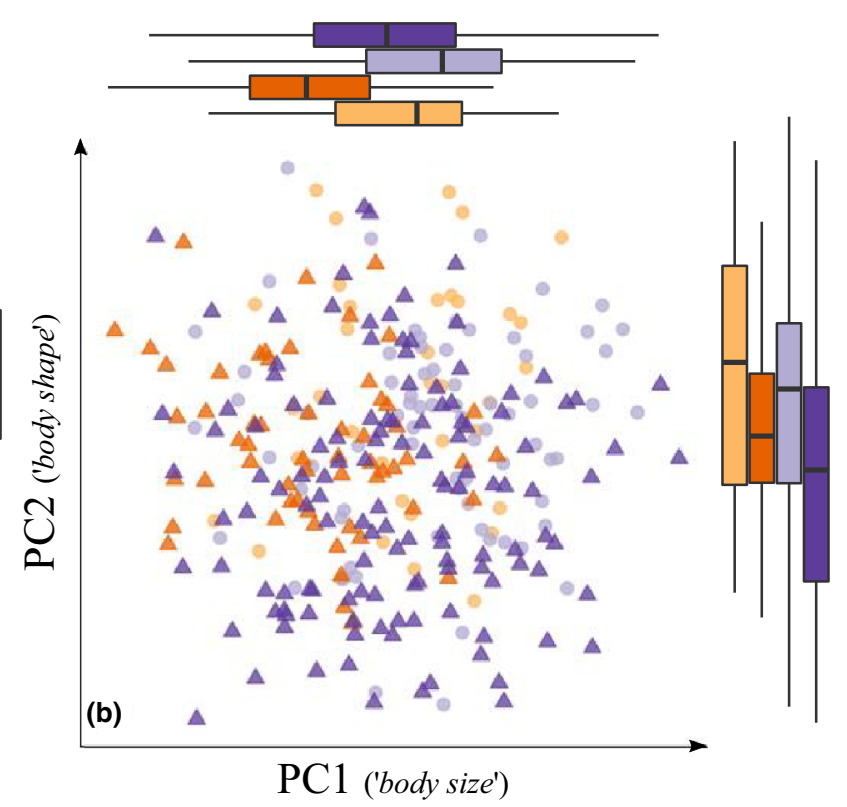

Plumage variables

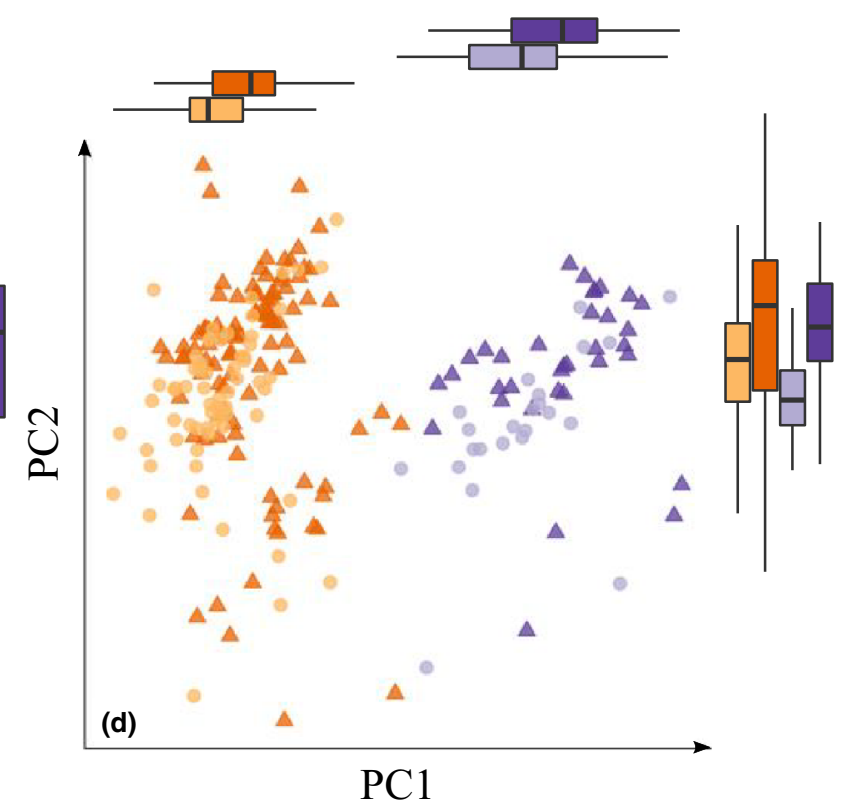

Figure 3. Scatter plots of the scores for the first two principal components (PCs) of variation in (a) skeletal variables, (b) external variables, (c) primary lengths and (d) plumage variables. Triangles indicate males; circles indicate females. The Common Snipe Gallinago gallinago and Wilson's Snipe Gallinago delicata are similar in size and shape of body and wing, but differ in plumage variables. Boxplots of the PCs scores for each species and sex are presented along the respective axis. The middle line indicates the median ( $50 \%$ quantile), whereas the lower and upper hinges correspond to 25 and $75 \%$ quantiles, respectively. The whiskers indicate the largest/smallest value within 1.5 times the interquartile range above the $75 \%$ quantile and below the $25 \%$ quantile, respectively. 
Table 3. Descriptive statistics of traits measured on skeletons and study skins (in $\mathrm{mm}$ ) of Common Snipe Gallinago gallinago and Wilson's Snipe G. delicata.

\begin{tabular}{|c|c|c|c|c|c|c|}
\hline & \multicolumn{3}{|l|}{ Common Snipe } & \multicolumn{3}{|l|}{ Wilson's Snipe } \\
\hline & Males & Females & SSD & Males & Females & SSD \\
\hline \multicolumn{7}{|l|}{ Skeletal variables } \\
\hline \multirow[t]{2}{*}{ Cranium } & $93.9 \pm 3.51(64)$ & $96.0 \pm 3.68(67)$ & -2.19 & $92.1 \pm 3.23(63)$ & $94.8 \pm 2.98(53)$ & -2.85 \\
\hline & $82.5-104.6$ & $86.6-104.5$ & & $85.4-101.1$ & $86.5-99.9$ & \\
\hline \multirow[t]{2}{*}{ Premaxilla } & $73.5 \pm 3.39(65)$ & $75.7 \pm 3.58(67)$ & -2.91 & $71.9 \pm 3.02(63)$ & $74.7 \pm 2.85(54)$ & -3.75 \\
\hline & $63.9-84.3$ & $65.9-83.8$ & & $65.1-79.8$ & $66.4-79.9$ & \\
\hline \multirow[t]{2}{*}{ Braincase* } & $20.5 \pm 0.66(64)$ & $20.4 \pm 0.72(65)$ & 0.49 & $20.4 \pm 0.57(61)$ & $20.3 \pm 0.55(53)$ & 0.49 \\
\hline & $18.6-22.5$ & $17.7-22.6$ & & $19.1-21.6$ & $18.9-21.5$ & \\
\hline \multirow[t]{2}{*}{ Sternum } & $47.8 \pm 1.27(73)$ & $48.6 \pm 1.74(74)$ & -1.65 & $46.8 \pm 1.32(66)$ & $47.4 \pm 1.56(59)$ & -1.27 \\
\hline & $45.2-50.9$ & $45.4-52.8$ & & $44.5-50.3$ & $43.9-51.4$ & \\
\hline \multirow[t]{2}{*}{ Keel length } & $50.9 \pm 1.62(72)$ & $51.3 \pm 2.14(76)$ & -0.78 & $49.4 \pm 1.43(67)$ & $49.6 \pm 1.68(59)$ & -0.40 \\
\hline & $47.2-54.3$ & $47.6-57.0$ & & $46.2-52.2$ & $46.3-53.8$ & \\
\hline \multirow[t]{2}{*}{ Keel depth } & $25.6 \pm 0.84(67)$ & $26.1 \pm 0.85$ & -1.92 & $25.0 \pm 0.89(63)$ & $25.6 \pm 0.88(60)$ & -2.34 \\
\hline & $23.8-27.2$ & $24.5-28.0$ & & $22.8-27.6$ & $23.8-27.8$ & \\
\hline \multirow[t]{2}{*}{ Coracoid } & $19.5 \pm 0.50(74)$ & $19.8 \pm 0.54(83)$ & -1.52 & $19.5 \pm 0.51(70)$ & $19.8 \pm 0.61(63)$ & -1.52 \\
\hline & $18.4-20.8$ & $18.4-21.0$ & & 18.0-20.6 & $18.3-21.3$ & \\
\hline \multirow[t]{2}{*}{ Humerus } & $36.8 \pm 0.94(74)$ & $37.9 \pm 0.90(81)$ & -2.90 & $37.2 \pm 0.87(68)$ & $38.0 \pm 1.04(62)$ & -2.11 \\
\hline & $34.8-38.7$ & $35.5-39.7$ & & $35.4-39.2$ & $35.1-40.1$ & \\
\hline \multirow[t]{2}{*}{ Radius } & $37.1 \pm 0.92(73)$ & $38.0 \pm 0.99(76)$ & -2.37 & $37.1 \pm 1.04(69)$ & $37.9 \pm 1.20(61)$ & -2.11 \\
\hline & $35.1-38.9$ & $35.9-41.0$ & & $34.8-40.2$ & $34.7-40.5$ & \\
\hline \multirow[t]{2}{*}{ Ulna } & $39.7 \pm 0.94(69)$ & $40.6 \pm 1.05(72)$ & -2.22 & $39.6 \pm 1.04(67)$ & $40.4 \pm 1.21(57)$ & -1.98 \\
\hline & $37.4-41.8$ & $37.4-43.2$ & & $37.5-42.5$ & $37.2-43.2$ & \\
\hline \multirow[t]{2}{*}{ Carpometacarpus } & $25.5 \pm 0.61(68)$ & $26.1 \pm 0.75(76)$ & -2.30 & $25.3 \pm 0.74(70)$ & $25.8 \pm 0.80(63)$ & -1.94 \\
\hline & $23.8-26.6$ & $24.5-27.7$ & & $24.1-27.7$ & $23.9-27.4$ & \\
\hline \multirow[t]{2}{*}{ Phalanx 1} & $10.5 \pm 0.39(68)$ & $10.6 \pm 0.41(80)$ & -0.94 & $10.3 \pm 0.34(69)$ & $10.5 \pm 0.47(59)$ & -1.90 \\
\hline & $9.4-11.3$ & $9.4-11.4$ & & $9.5-11.1$ & $9.6-11.4$ & \\
\hline \multirow[t]{2}{*}{ Ischial length } & $34.4 \pm 1.03(72)$ & $35.4 \pm 1.16(79)$ & -2.82 & $34.7 \pm 1.12(71)$ & $35.5 \pm 1.23(63)$ & -2.25 \\
\hline & $32.4-37.4$ & $32.8-38.5$ & & $32.1-36.8$ & $32.1-37.6$ & \\
\hline \multirow[t]{2}{*}{ Ischial depth } & $7.0 \pm 0.31(73)$ & $7.2 \pm 0.37(79)$ & -2.78 & $7.0 \pm 0.39(71)$ & $7.1 \pm 0.35(63)$ & -1.41 \\
\hline & $6.3-7.7$ & $6.5-8.1$ & & $6.1-8.0$ & $6.3-8.0$ & \\
\hline \multirow[t]{2}{*}{ Femur } & $31.2 \pm 1.00(78)$ & $32.4 \pm 1.06(78)$ & -3.70 & $31.7 \pm 0.84(69)$ & $32.5 \pm 0.91(61)$ & -2.46 \\
\hline & $28.8-33.2$ & $29.8-35.6$ & & $29.9-33.8$ & $29.8-34.5$ & \\
\hline \multirow[t]{2}{*}{ Tibiotarsus } & $55.5 \pm 1.70(68)$ & $54.8 \pm 1.55(71)$ & 1.28 & $53.9 \pm 1.70(66)$ & $54.8 \pm 1.90(58)$ & -1.64 \\
\hline & $49.0-57.3$ & $52.0-59.6$ & & $51.2-57.9$ & $48.9-58.5$ & \\
\hline Tarsometatarsus & $33.0 \pm 1.33(74)$ & $33.8 \pm 1.12(83)$ & -2.37 & $32.5 \pm 1.14(69)$ & $33.3 \pm 1.40(64)$ & -2.40 \\
\hline & $29.6-36.2$ & $31.1-36.5$ & & $30.1-35.8$ & $28.6-36.0$ & \\
\hline External variables & & & & & & \\
\hline Bill & $64.7 \pm 3.64(169)$ & $66.9 \pm 3.44(100)$ & -3.29 & $62.4 \pm 2.80(130)$ & $64.8 \pm 3.31(95)$ & -3.70 \\
\hline & $57.0-75.9$ & $60.0-76.4$ & & $56.1-69.6$ & $57.1-73.1$ & \\
\hline Tarsus & $32.2 \pm 1.44(175)$ & $32.8 \pm 1.37(104)$ & -1.83 & $31.9 \pm 1.04(129)$ & $32.7 \pm 1.36(97)$ & -2.45 \\
\hline & $28.5-35.8$ & $29.7-36.4$ & & $29.4-34.7$ & $30.0-36.3$ & \\
\hline Tail & $56.6 \pm 2.92(154)$ & $55.42 \pm 2.63(95)$ & 2.13 & $53.3 \pm 2.52(82)$ & $53.2 \pm 2.82(52)$ & 0.19 \\
\hline & $49.0-62.0$ & $48.0-61.0$ & & $47.0-58.0$ & $46.0-58.0$ & \\
\hline Wing & $131.4 \pm 4.06(156)$ & $131.9 \pm 3.75(86)$ & -0.38 & $131.4 \pm 3.19(109)$ & $132.4 \pm 3.35(79)$ & -0.76 \\
\hline & $122.0-140.0$ & $123.0-140.0$ & & $122.0-138.0$ & $125.0-141.0$ & \\
\hline Plumage variables & & & & & & \\
\hline Outer rectrix vane length & $53.9 \pm 2.77(175)$ & $50.0 \pm 2.92(106)$ & 7.80 & $46.7 \pm 2.78(195)$ & $44.2 \pm 2.59(145)$ & 5.66 \\
\hline & $45.0-60.0$ & $42.0-59.0$ & & $40.0-55.0$ & $37.0-52.0$ & \\
\hline Outer rectrix vane width & $11.9 \pm 1.16(171)$ & $11.7 \pm 1.12(100)$ & 1.71 & $8.3 \pm 0.64(195)$ & $8.4 \pm 0.68(145)$ & -1.19 \\
\hline & $9.0-15.5$ & $8.5-14.0$ & & $6.5-10.0$ & $6.5-10.5$ & \\
\hline White in the secondaries & $4.1 \pm 1.11(182)$ & $3.6 \pm 0.82(113)$ & 13.89 & $1.3 \pm 0.38(206)$ & $1.2 \pm 0.34(154)$ & 8.33 \\
\hline & $1.3-7.2$ & $1.6-5.7$ & & $0.4-2.4$ & $0.4-2.3$ & \\
\hline
\end{tabular}


Table 3. (continued)

\begin{tabular}{|c|c|c|c|c|c|c|}
\hline & \multicolumn{3}{|l|}{ Common Snipe } & \multicolumn{3}{|l|}{ Wilson's Snipe } \\
\hline & Males & Females & SSD & Males & Females & SSD \\
\hline White in the axillaries & $0.7 \pm 0.14(39)$ & $0.7 \pm 0.17(27)$ & 0.00 & $0.4 \pm 0.06(105)$ & $0.4 \pm 0.06(74)$ & 0.00 \\
\hline & $0.6-1.0$ & $0.4-1.0$ & & $0.3-0.6$ & $0.2-0.6$ & \\
\hline \multicolumn{7}{|l|}{ No. of rectrices } \\
\hline 12 & (9) & $(5)$ & & (5) & (1) & \\
\hline 14 & (192) & $(108)$ & & (30) & (21) & \\
\hline 16 & (4) & (2) & & (182) & (132) & \\
\hline 18 & - & - & & (3) & (1) & \\
\hline
\end{tabular}

Cell entries are mean \pm se $(n)$, and the range. SSD (sexual size dimorphism) $=100(($ male/female) -1$)$. *Derived trait, Braincase $=$ Cranium - Premaxilla .

these axes except for $\mathrm{PCl}$ of external variables (i.e. body size). The difference for (external) body size between Common Snipe and Wilson's Snipe was larger among males. On the other hand, for both species, differences between males and females were more prominent on skeletal and external variables than on four of the five plumage variables (Fig. 5b). The exception was the length of the outermost rectrix, which was the most sexually dimorphic plumage variable.

\section{DISCUSSION}

Selection usually is suggested as responsible for phenotypic differences between allopatric populations; however, they also might diverge through neutral evolutionary processes such as drift (Mayr 1954, Lande 1976, 1980). The beta-test results suggest that drift alone cannot explain differences in skeleton, wing or plumage between the Common Snipe and Wilson's Snipe, and thus selection was probably responsible for the divergence. However, the null hypothesis could not be rejected after adjusting the level of significance for multiple comparisons. This hypothesis is difficult to reject when few taxa are compared, and a significant result in any single test probably indicates selection (Ackermann \& Cheverud 2004).

The Common Snipe has a larger sternum than Wilson's Snipe, but otherwise the species do not differ in skeletal size. Sternal size is related to volume of the pectoral muscles (Piersma et al. 1984), which are responsible for powered flight and nutrient storage (Lindström \& Piersma 1993, Lindström et al. 2000). Migratory species of passerines have larger sterna than their sedentary congeneric relatives, and sternal size within migratory Sylvia species is correlated with migration distance (Calmaestra \& Moreno 1998, 2000). The distances between centroids of the breeding and wintering ranges of the Common Snipe (c. $5600 \mathrm{~km}$ ) and Wilson's Snipe (c. $3000 \mathrm{~km}$ ) suggest an almost two-fold higher total migration distance in the Common Snipe, which can explain its relatively larger sternum. However, because both Common Snipe and Wilson's Snipe also perform aerial displays, it is difficult to provide a qualified interpretation for the difference we found. A comparative study of skeletons of sedentary and migratory snipes would help in better understanding this pattern.

The species did not differ in wing size or pointedness, traits that are usually related to flight distance (Fernandez \& Lank 2007, Milá et al. 2008, Baldwin et al. 2010, Forschler \& Bairlein 2011, Minias et al. 2015), relative fuel load (Burns 2003) and manoeuvrability (Hedenström \& Møller 1992, Burns \& Ydenberg 2002). This was an unexpected finding in light of the difference observed in sternal size between the species. Differences in wing morphology may develop rapidly in response to selective pressures (Lank et al. 2017, Anderson et al. 2019) and may occur between conspecific populations. For instance, during autumn migration of Common Snipe in central Poland, Minias et al. (2013) observed that first-year late migrants had longer and more rounded wings than those migrating early in the season, probably due to differences in their origin. However, a comparative study between migratory and sedentary Common Snipe found no differences in wing shape, suggesting a possible influence of display behaviour, and 
Skeletal variables

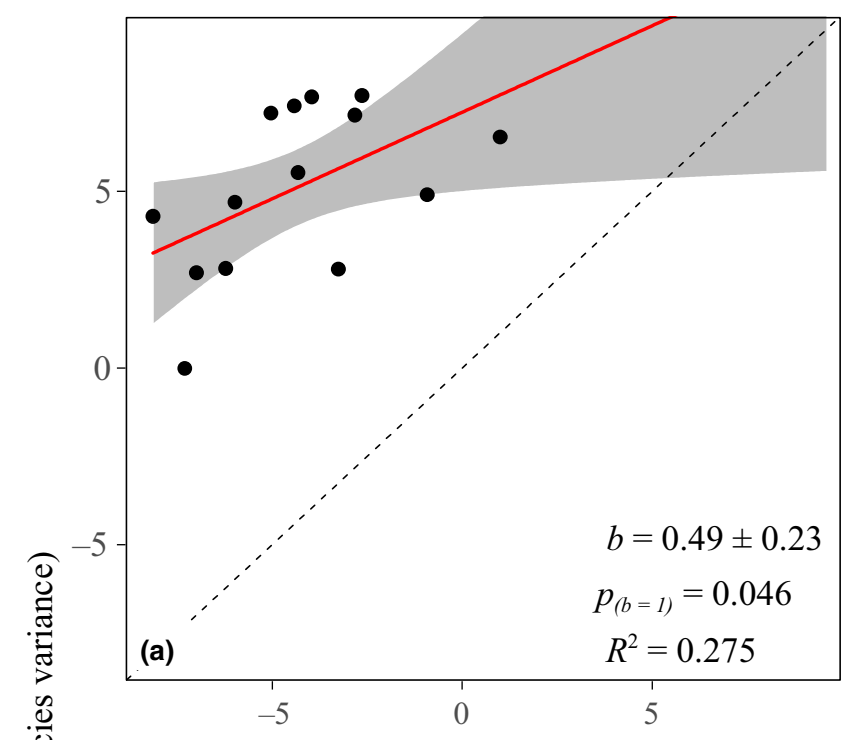

\section{Primary lengths}

है

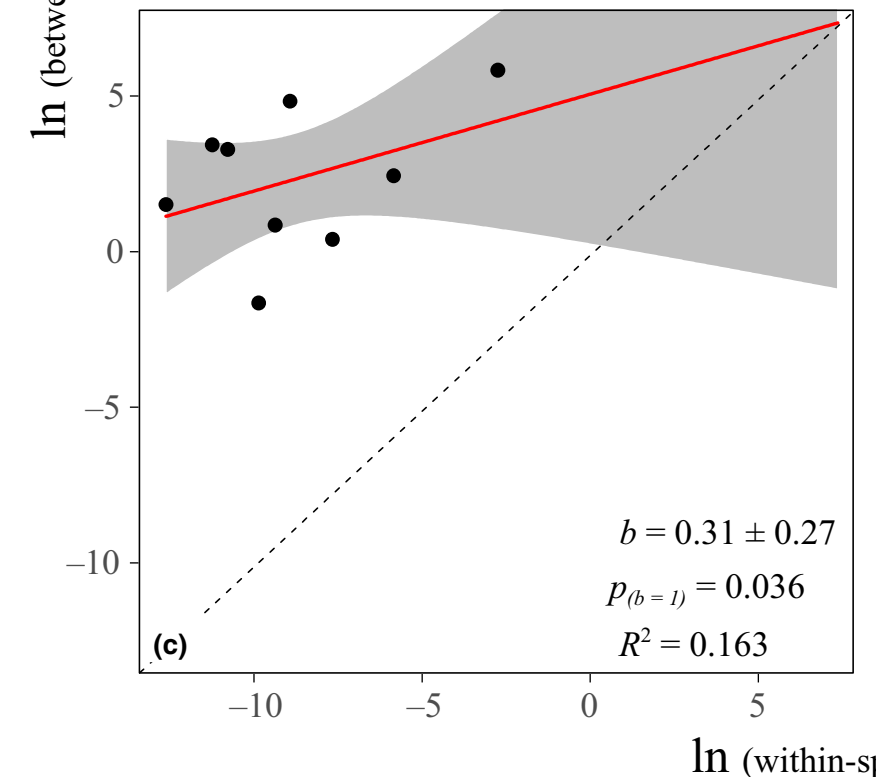

External variables

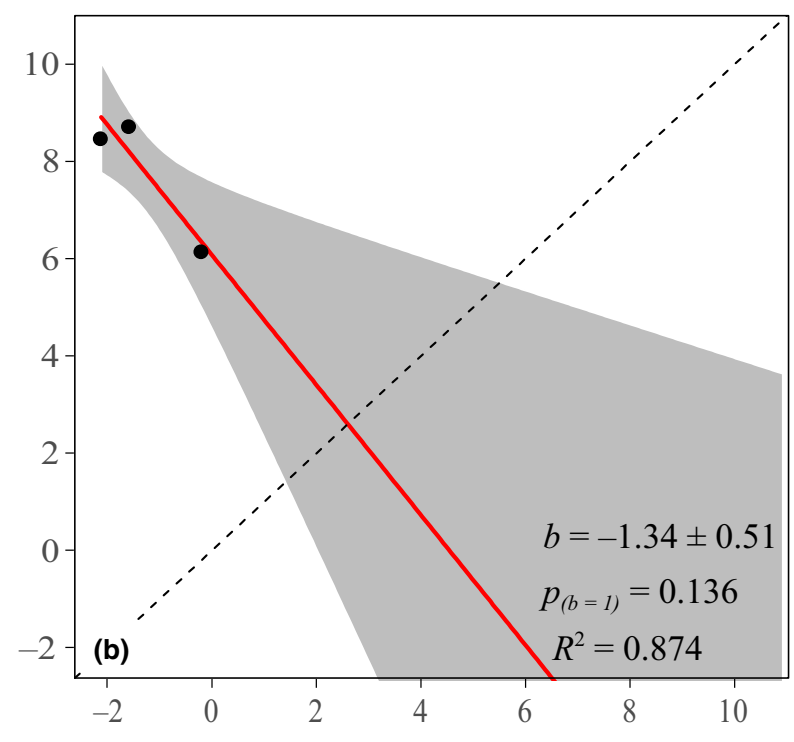

Plumage variables

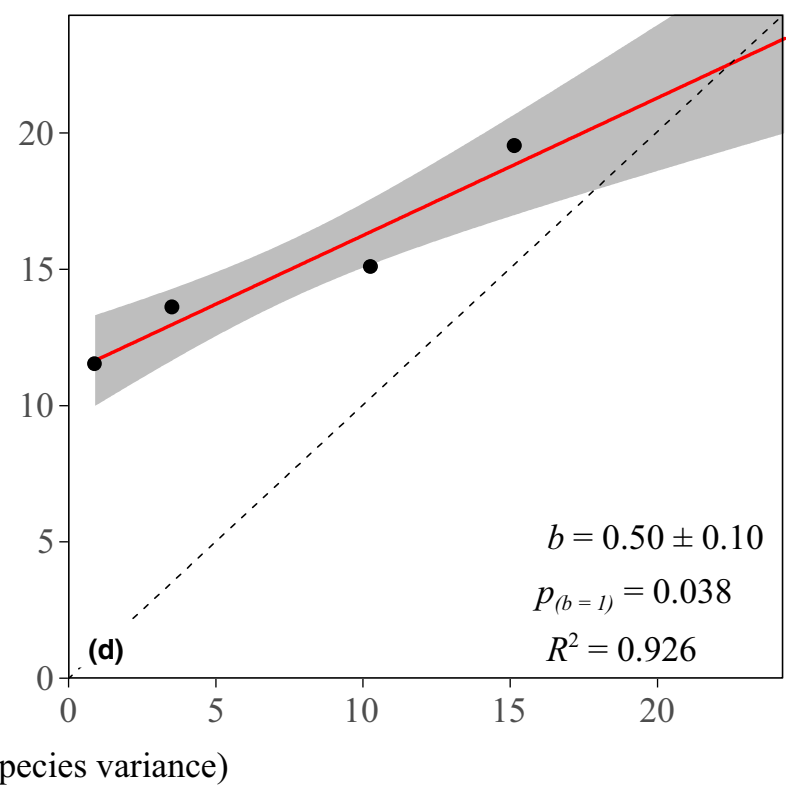

Figure 4. Regression of between-species and within-species variance on (a) skeletal variables, (b) external variables, (c) primary lengths and (d) plumage variables of the Common Snipe Gallinago gallinago and Wilson's Snipe Gallinago delicata.

thus social selection, on this trait (Rodrigues et al. 2018).

Species differences in skeleton and external measurements are small compared with those in plumage traits, suggesting that the latter diverged more rapidly. The Common Snipe has fewer rectrices, longer and wider outermost rectrices, more extensive white on tips of the secondary feathers, and more white in the axillaries. Both species expose these parts of their body in various ground 


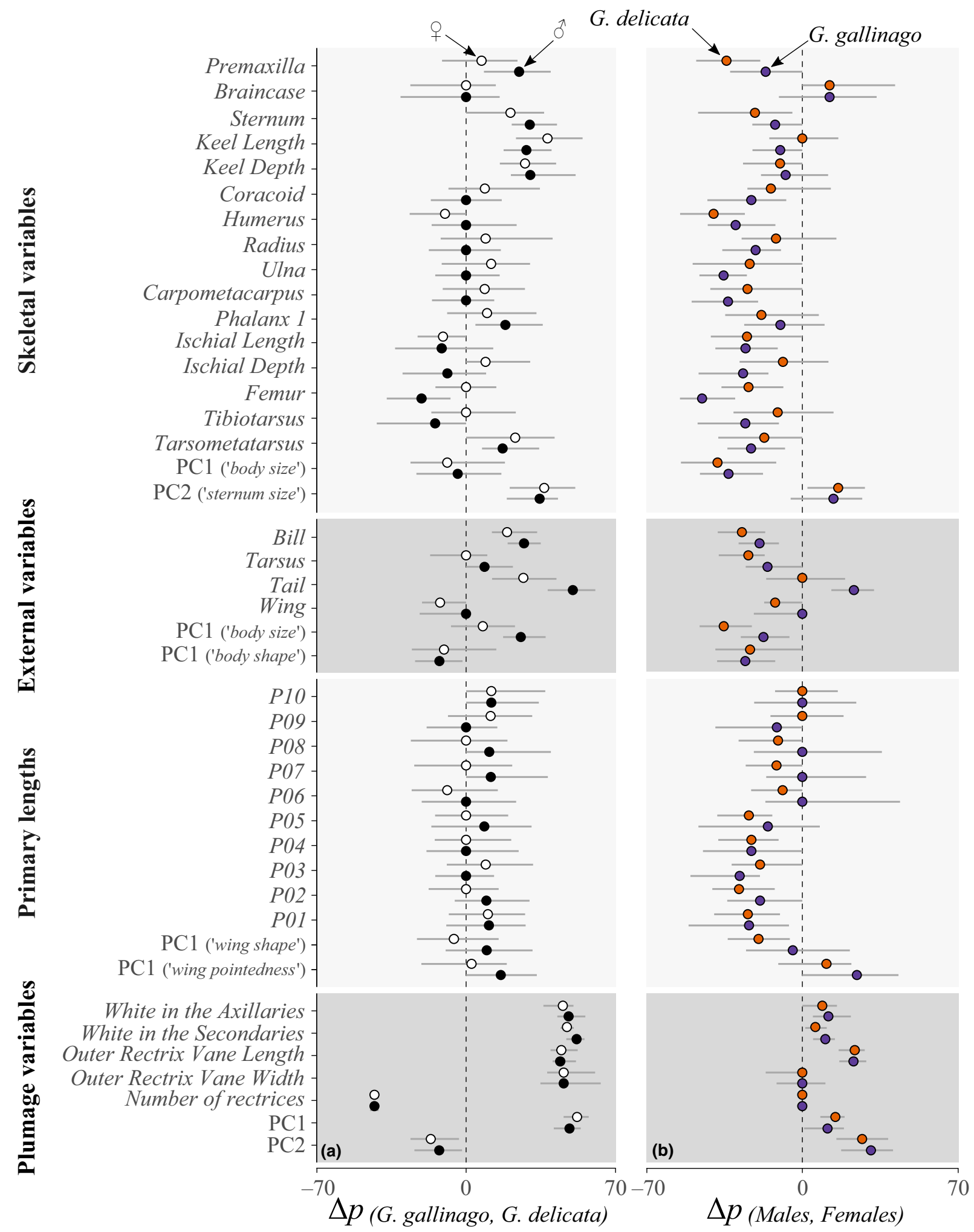

Figure 5. Summary of phenotypic distances between (a) Common Snipe Gallinago gallinago and Wilson's Snipe Gallinago delicata, and (b) males and females ( $\triangle p$; Safran et al. 2012) for each variable and multivariate axis. Horizontal lines correspond to $95 \%$ confidence intervals (estimated by bootstrapping). Primaries are numbered from body toward the wing tip. The species differ more in plumage variables than in most skeletal and external variables. 
and aerial displays, and also use the rectrices to produce instrumental sounds in aerial displays (Tuck 1972, Sutton 1981, Cramp \& Simmons 1983, Glutz von Blotzheim et al. 1986), so social selection potentially played a role in their evolutionary differentiation.

Most Common Snipe and Wilson's Snipe specimens examined had 14 and 16 rectrices, respectively, but the number varied substantially (Common Snipe, 12-16; Wilson's Snipe, 12-18). These findings agree with previous information (Tuck 1972, Cramp \& Simmons 1983, Glutz von Blotzheim et al. 1986) except that we noted no specimens of Common Snipe with 18 rectrices. The number of rectrices varies substantially across snipe species (Seebohm 1888, Tuck 1972). Seebohm (1888) mused that interspecific variation in the number of rectrices would eventually be explained by sexual selection. At least in the Latham's Snipe Gallinago hardwickii, the number differs between sexes (Ura et al. 2005). In the Common Snipe and Wilson's Snipe, males seemed to have relatively more rectrices compared with females in multivariate analysis but the number of rectrices alone did not differ between sexes (Table 3).

The vanes of the outer rectrices were wider and longer in the Common Snipe than in the Wilson's Snipe, in agreement with other accounts (Tuck 1972), probably contributing to differences in drumming sounds between the species (CarrLewty 1943, Thönen 1969, Byrd \& Gibson 1978, Miller 1996, Arkhipov 2009, van Casteren et al. 2010, Clark \& Prum 2015). These feathers have evolved morphological modifications to cope with the demands of sound production during aerial displays (Bahr 1907, van Casteren et al. 2010, Clark \& Prum 2015). In the Common Snipe, the angle between the barbs and the rachis is reduced in the outermost rectrices, when compared with other non-sound-producing rectrices, or with the outermost rectrices of the Eurasian Woodcock Scolopax rusticola. Additionally, the morphology of the barbules in the hind vane varies with distance from the rachis (van Casteren et al. 2010). A recent study found an inverse correlation between the structural quality (evaluated by mass-length residuals) and the brightness of the outer rectrices in the Common Snipe, suggesting that the mechanical properties of these feathers might benefit from melanization and that both social selection and natural selection might have influenced evolution of melanin-based coloration of these feathers (Minias et al. 2018).

The larger white markings at the tips of the secondaries and the higher proportion of white in the axillaries of the Common Snipe resemble some differences between other scolopacids of the Palaearctic and Nearctic (Prater et al. 1977). Because scolopacids expose these traits during displays (Miller 1984), they probably have a function in communication, so social selection is likely to have played a role in the evolution of clear taxonspecific signalling. Natural selection, in addition to social selection, might promote differences in social traits between allopatric populations by shaping them according to the physical properties of their habitats (Boncoraglio \& Saino 2007, Tobias et al. 2010) or as a by-product of adaptive divergence (Servedio et al. 2011, Wilkins et al. 2013). For instance, ambient light can affect the evolution of colour and optical communication in fish (Fuller 2002, Seehausen et al. 2008), reptiles (Leal \& Fleishman 2002) and birds (Marchetti 1993, Bloch 2015, but see Anciães \& Prum 2008). However, differences in plumage between the Common Snipe and Wilson's Snipe are subtle and would only be detected over short distances, when environmental effects would be minimal.

All analyses revealed sexual differences between the Common Snipe and Wilson's Snipe. Females have larger bodies and wings than males, but their sterna are relatively smaller, the wings are less pointed, and the rectrices are shorter. Many studies support a role of sexual selection in the evolution of SSD in birds (Székely et al. 2000, 2004, Drovetski et al. 2006). However, for the Common Snipe, in which only females incubate the eggs (Tuck 1972, Green et al. 1990, Green 1991), the less pointed wingtips in females were interpreted to be a result of natural selection acting on more efficient take-off performance and predator escape (Minias et al. 2013). This hypothesis is supported by the results of a study in Calidris sandpipers (Burns \& Ydenberg 2002), but Tuck's (1972) anecdotal records on Wilson's Snipe and systematic observations on the Great Snipe (Höglund et al. 1992) suggest snipes rely on their cryptic plumage, freezing, hiding or ignoring potential predators rather than by flying away. Alternatively, the smaller bodies and wings of males could increase agility in aerial displays (Székely et al. 2000, 2004). The more pointed wings, besides influencing the wingtip vortices (Lockwood et al. 
1998), may increase flight speed, due to their higher loading (Rayner 1988), thus improving aerial display performance. The drumming sound of the Common Snipe is audible when air speed is between 12 and $42 \mathrm{~m} / \mathrm{s}$, during the diving part of the drumming flight (Carr-Lewty 1943, Reddig 1978, Sutton 1981, van Casteren et al. 2010). Tuck (1972) commented that females are unable to produce a drumming sound because they cannot dive at the necessary speed and angle for the outer rectrices to vibrate. This difference in behaviour can also explain the sexual differences found in the relative size of the sternum and shape of the wingtip. Other contributing factors to the observed sexual size dimorphism could include diet, habits, habitat use and migration between males and females (Green et al. 1990, Green 1991, Devort 1997, McCloskey \& Thompson 2000, McCloskey et al. 2009, Cline \& Haig 2011).

In summary, we observed stronger differences between Common Snipe and Wilson's Snipe in plumage characters, which probably have important signalling functions, than in traits related to resource use. These findings suggest that traits under social selection diverged more rapidly than those under natural selection in the two species, in agreement with differing rates and strengths of social and natural selection (Panhuis et al. 2001, Kingsolver \& Pfennig 2007, Safran et al. 2013). However, tests of the null hypothesis yielded borderline results, so adding other species of snipe and more traits (including acoustic data), or replicating this study, might strengthen this conclusion.

For collection access and assistance, we thank: Simon J. M. Davis, Zooarqueologia, Laboratório de Arqueociências, $D G P C$ (formerly IGESPAR, formerly IPA); Kristof Zyskowski, Yale Peabody Museum of Natural History; James Dean and Brian Schmidt, National Museum of Natural History; Alan Baker and Mark Peck, Royal Ontario Museum; John Bates and Dave Willard, Field Museum of Natural History; Janet Hinshaw, University of Michigan Museum of Zoology; George Barrowclough, Paul Sweet, Peter Capainolo and Selena Flores, American Museum of Natural History; Luzia Sousa, Natural History Museum of the University of Porto; Igor Fadeev, State Darwin Museum, Pavel Tomkovich and Yaroslav Redkin, Zoological Museum of Moscow University; José Pedro Granadeiro, National Museum of Natural History and Science, University of Lisbon; Jan Bolding, Natural History Museum of Denmark; and Nathalie DjanChékar, The Rooms Corporation of Newfoundland and Labrador. For specimen loans, we thank: Robert Faucet, Burke Museum of Natural History and Culture;
Kimberly Bostwick and Charles Dardia, Cornell University Museum of Vertebrates; Jean Woods, Delaware Museum of Natural History; Carla Cicero, Museum of Vertebrate Zoology, University of California; John Demboski and Jeff Stephenson, Denver Museum of Nature and Science; Mark Robbins, University of Kansas Biodiversity Institute; Kimball Garret, Natural History Museum of Los Angeles County; and Gary Schnell and Tamaki Yuri, Sam Noble Oklahoma Museum of Natural History, University of Oklahoma. We also thank Igor Fadeev for the translation of hundreds of specimen tags hand written in Russian, the matching of the collection places to the new toponomy of the former USSR and Russian Empire, and the georeferencing of specimens. Hosein Yusefi helped with georeferencing of old specimens from Persia. T.M.R. would like to thank Isa Ribeiro, Pedro Andrade, Vanessa Mata, Keith Lewis, Antigoni Kaliontzopoulou and many other colleagues at the Conservation Genetics and Wildlife Management Journal Club for their inputs and discussions during the preparation of the manuscript. T.M.R. would also like to express his appreciation to Kristof Zyskowski, Yulia Bereshpolova, Chih-Ming Hung, Vyacheslav Drovetski and Nadezhda Drovetskaya for their assistance provided while visiting collections.

T.M.R.'s visits to North American institutions were funded by Fundação Luso Americana para o Desenvolvimento (Proj. L07-V-009/2011), a Collection Study Grant from the American Museum of Natural History, and FEDER funds through the Operational Programme for Competitiveness Factors - COMPETE and by National Funds through FCT -Foundation for Science and Technology under the PTDC/BIA-BIC/3966/2012 and FCOMP-01-0124-FEDER-028301; the last also supported T.M.R.'s research fellowship. The Synthesys programme sponsored T.M.R.'s visit to the Natural History Museum of Denmark (Proj. DK-TAF2513).

Standard and required practices for examining specimens in natural history museums were followed. Loans from the American Museum of Natural History, Burke Museum of Natural History and Culture, Cornell University Museum of Vertebrates, Delaware Museum of Natural History, Museum of Vertebrate Zoology, University of California, Denver Museum of Nature and Science, University of Kansas Biodiversity Institute, Natural History Museum of Los Angeles County, and Sam Noble Oklahoma Museum of Natural History, University of Oklahoma were received at the Bell Museum, University of Minnesota.

\section{AUTHOR CONTRIBUTIONS}

Tiago M Rodrigues: Conceptualization (equal); Data curation (lead); Formal analysis (lead); Funding acquisition (supporting); Investigation (equal); 
Methodology (equal); Writing-original draft (lead); Writing-review \& editing (equal). Edward $\mathrm{H}$. Miller: Formal analysis (supporting); Methodology (equal); Supervision (supporting); Writing-review \& editing (equal). Sergei V. Drovetski: Conceptualization (equal); Funding acquisition (supporting); Methodology (equal); Supervision (supporting); Writing-review \& editing (supporting). Robert Zink: Funding acquisition (supporting); Methodology (equal); Writing-review \& editing (supporting). Jon Fjeldsa: Funding acquisition (supporting); Writing-review \& editing (supporting). David Afonso Gonçalves: Conceptualization (equal); Formal analysis (supporting); Funding acquisition (lead); Investigation (lead); Methodology (equal); Supervision (lead); Writing-review \& editing (supporting).

\section{DATA AVAILABILITY STATEMENT}

The data that support the findings of this study are available in Dryad at https://doi.org/10.5061/ dryad.02v6wwq0s (Rodrigues et al. 2020).

\section{REFERENCES}

Ackermann, R.R. \& Cheverud, J.M. 2002. Discerning evolutionary processes in patterns of tamarin (genus Saguinus) craniofacial variation. Am. J. Phys. Anthropol. 117: 260-271.

Ackermann, R.R. \& Cheverud, J.M. 2004. Detecting genetic drift versus selection in human evolution. Proc. Natl. Acad. Sci. USA 101: 17946-17951.

Anciães, M. \& Prum, R.O. 2008. Manakin display and visiting behaviour: a comparative test of sensory drive. Anim. Behav. 75: 783-790.

Anderson, A.M., Friis, C., Gratto-Trevor, C.L., Morrison, R.I.G., Smith, P.A. \& Nol, E. 2019. Consistent declines in wing lengths of calidridine sandpipers suggest a rapid morphometric response to environmental change. PLoS One 14: e0213930.

Arkhipov, V.Y. 2009. The first record of Wilson's Snipe (Gallinago (g.) delicata) in Russia and comments on its taxonomic status. (in Russian). Zool. Zh. 88: 1146-1149.

Armstrong, C., Richardson, D.S., Hipperson, H., Horsburgh, G.J., Küpper, C., Percival-Alwyn, L., Clark, M., Burke, T. \& Spurgin, L.G. 2018. Genomic associations with bill length and disease reveal drift and selection across island bird populations. Evol. Lett. 2: 22-36.

Bahr, P.H. 1907. On the 'bleating' or 'drumming' of the snipe (Gallinago coelestis). Proc. Zool. Soc. Lond. 77: 12-35.

Baker, A.J., Tavares, E.S. \& Elbourne, R.F. 2009. Countering criticisms of single mitochondrial DNA gene barcoding in birds. Mol. Ecol. Resour. 9: 257-268.

Baldwin, M.W., Winkler, H., Organ, C.L. \& Helm, B. 2010. Wing pointedness associated with migratory distance in common-garden and comparative studies of Stonechats (Saxicola torquata). J. Evol. Biol. 23: 1050-1063.
Baumel, J.J. \& Witmer, L.M. 1993. Osteologia. In Baumel, J.J., King, A.S., Breazile, J.E., Evans, H.E. \& Vanden Berge, J.C. (eds) Handbook of Avian Anatomy: Nomina Anatomica Avium: 45-132. Cambridge, MA: Publications of the Nuttall Ornithological Club 23.

BirdLife International \& NatureServe 2015. Bird Species Distribution Maps of the World. Cambridge: BirdLife International, and Arlington, VA: NatureServe.

Bloch, N.I. 2015. Evolution of opsin expression in birds driven by sexual selection and habitat. Proc. $R$. Soc. B 282: 20142321.

Boncoraglio, G. \& Saino, N. 2007. Habitat structure and the evolution of bird song: a meta-analysis of the evidence for the acoustic adaptation hypothesis. Funct. Ecol. 21: 134-142.

Bordkorb, P. 1967. Catalogue of fossil birds: part 3 (Ralliformes, Ichthyornithiformes, Charadriformes). Bull. Fla. Mus. Nat. Hist. Biol. Sci. 2: 99-220.

Burns, J.G. 2003. Relationship of Calidris sandpiper wing shape with relative fuel load and total migration distance. Auk 120: 827-835.

Burns, J.G. \& Ydenberg, R.C. 2002. The effects of wing loading and gender on the escape flights of Least Sandpipers (Calidris minutilla) and Western Sandpipers (Calidris mauri). Behav. Ecol. Sociobiol. 52: 128-136.

Byrd, G.V. \& Gibson, D.D. 1978. New information on Asiatic birds in the Aleutian Islands, Alaska. Condor 80: 309-315.

Calmaestra, R.G. \& Moreno, E. 1998. Ecomorphological patterns related to migration in the genus Sylvia: an osteological analysis. Ardeola 45: 21-27.

Calmaestra, R.G. \& Moreno, E. 2000. Ecomorphological patterns related to migration: a comparative osteological study with passerines. J. Zool. 252: 495-501.

Carr-Lewty, R.A. 1943. The aerodynamics of the drumming of the Common Snipe. Br. Birds 36: 230-234.

van Casteren, A., Codd, J.R., Gardiner, J.D., McGhie, H. \& Ennos, A.R. 2010. Sonation in the male Common Snipe (Capella gallinago gallinago L.) is achieved by a flag-like fluttering of their tail feathers and consequent vortex shedding. J. Exp. Biol. 213: 1602-1608.

Cattell, R.B. 1966. The scree test for the number of factors. Multivar. Behav. Res. 1: 245-276.

Clark, C.J. \& Prum, R.O. 2015. Aeroelastic flutter of feathers, flight and the evolution of non-vocal communication in birds. J. Exp. Biol. 218: 3520-3527.

Cline, B.B. \& Haig, S.M. 2011. Seasonal movements, residency, and migratory patterns of Wilson's Snipe (Gallinago delicata). Auk 128: 543-555.

Cohen, S.B. \& Dor, R. 2018. Phenotypic divergence despite low genetic differentiation in House Sparrow populations. Sci. Rep. 8: 394.

Cornuault, J., Delahaie, B., Bertrand, J.A.M., Bourgeois, Y.X.C., Milá, B., Heeb, P. \& Thébaud, C. 2015. Morphological and plumage colour variation in the Réunion Grey White-eye (Aves: Zosterops borbonicus): assessing the role of selection. Biol. J. Linn. Soc. 114: 459-473.

Coyne, J.A., Barton, N.H. \& Turelli, M. 1997. A critique of Sewall Wright's shifting balance theory of evolution. Evolution 51: 643-671.

Coyne, J.A. \& Orr, H.A. 2004. Speciation. Sunderland, MA: Sinauer Associates.

Cramp, S. \& Simmons, K.E.L. 1983. Handbook of the Birds of Europe, the Middle East and North Africa: the Birds of the 
Western Palearctic. Vol. 3: Waders to Gulls Oxford: Oxford University Press.

Czajkowski, A. 2002. Key to Ageing and Sexing of the Common Snipe Gallinago gallinago by the Study of Feathers. Paris: Oiseaux Migrateurs du Paléarctique Occidental.

Darwin, C. 1859. On the Origin of Species by Means of Natural Selection, or the Preservation of Favoured Races in the Struggle for Life. London: John Murray.

Darwin, C. 1871. The Descent of Man, and Selection in Relation to Sex. London: John Murray.

Devort, M. 1997. The Common Snipe. Elements of an Action Plan. Paris: Oiseaux Migrateurs du Paléarctique Occidental.

Drovetski, S.V., Rohwer, S. \& Mode, N.A. 2006. Role of sexual and natural selection in evolution of body size and shape: a phylogenetic study of morphological radiation in grouse. J. Evol. Biol. 19: 1083-1091.

Eck, S., Fiebig, J., Fiedler, W., Heynen, I., Nicolai, B., Töpfer, T., van den Elzen, R., Winkler, R. \& Woog, F. 2011. Measuring Birds - Vögel Vermessen. Minden: Christ Media Natur.

Evered, D.S. 1990. Measures of wing area and wing span from wing formula data. Auk 107: 784-787.

Fernandez, G. \& Lank, D.B. 2007. Variation in the wing morphology of Western Sandpipers (Calidris mauri) in relation to sex, age class, and annual cycle. Auk 124: 10371046.

Forschler, M.I. \& Bairlein, F. 2011. Morphological shifts of the external flight apparatus across the range of a passerine (Northern Wheatear) with diverging migratory behaviour. PLoS One 6: e18732.

Friis, G. \& Milá, B. 2020. Change in sexual signaling traits outruns morphological divergence in a recent avian radiation across an ecological gradient. J. Evol. Biol. 33: 1276-1293.

Fuller, R.C. 2002. Lighting environment predicts the relative abundance of male colour morphs in bluefin killifish (Lucania goodel) populations. Proc. R. Soc. B 269: 1457-1465.

Geue, J.C., Vágási, C.I., Schweizer, M., Pap, P.L. \& Thomassen, H.A. 2016. Environmental selection is a main driver of divergence in House Sparrows (Passer domesticus) in Romania and Bulgaria. Ecol. Evol. 6: 7954 7964.

Gill, F. \& Donsker, D. 2019. IOC World Bird List (v9.1).

Glutz von Blotzheim, U.N., Bauer, K.M. \& Bezzel, E. 1986. Handbuch der Vögel Mitteleuropas, Band 7: Charadriiformes (2. Teil). Wiesbaden: Akademische Verlagsgesellschaft.

Green, R.E. 1991. Sex differences in the behaviour and measurements of the Common Snipe Gallinago gallinago breeding in Cambridgeshire, England. Ring. Migr. 12: 57-60.

Green, R.E., Hirons, G.J.M. \& Cresswell, B.H. 1990. Foraging habitats of female Common Snipe Gallinago gallinago during the incubation period. J. Appl. Ecol. 27: 325-335.

Hedenström, A. \& Møller, A.P. 1992. Morphological adaptations to song flight in passerine birds: a comparative study. Proc. R. Soc. B 247: 183-187.

Höglund, J., Kålås, J.A. \& Fiske, P. 1992. The costs of secondary sexual characters in the lekking Great Snipe (Gallinago media). Behav. Ecol. Sociobiol. 30: 309-315.

Holand, A.M., Jensen, H., Tufto, J. \& Moe, R. 2011. Does selection or genetic drift explain geographic differentiation of morphological characters in House Sparrows Passer domesticus? Genet. Res. 93: 367-379.

Johnsen, A., Rindal, E., Ericson, P.G.P., Zuccon, D., Kerr, K.C.R., Stoeckle, M.Y. \& Lifjeld, J.T. 2010. DNA barcoding of Scandinavian birds reveals divergent lineages in transAtlantic species. J. Ornithol. 151: 565-578.

Kaiser, H.F. 1960. The application of electronic computers to factor analysis. Educ. Psychol. Meas. 20: 141-151.

Kekkonen, J., Jensen, H. \& Brommer, J.E. 2012. Morphometric differentiation across House Sparrow Passer domesticus populations in Finland in comparison with the neutral expectation for divergence. Ibis 154: 846-857.

Kerr, K.C.R., Birks, S.M., Kalyakin, M.V., Red'kin, Y.A., Koblik, E.A. \& Hebert, P.D.N. 2009. Filling the gap - COI barcode resolution in eastern Palearctic birds. Front. Zool. 6: 29.

Kingsolver, J.G. \& Pfennig, D.W. 2007. Patterns and power of phenotypic selection in nature. Bioscience 57: 561-572.

Lande, R. 1976. Natural selection and random genetic drift in phenotypic evolution. Evolution 30: 313-334.

Lande, R. 1979. Quantitative genetic analysis of multivariate evolution, applied to brain: body size allometry. Evolution 33: 402-416.

Lande, R. 1980. Genetic variation and phenotypic evolution during allopatric speciation. Am. Nat. 116: 463-479.

Lank, D.B., Xu, C., Harrington, B.A., Morrison, R.I.G., Gratto-Trevor, C.L., Hicklin, P.W., Sandercock, B.K., Smith, P.A., Kwon, E., Rausch, J., Dominix, L.D.P., Hamilton, D.J., Paquet, J., Bliss, S.E., Neima, S.G., Friis, C., Flemming, S.A., Anderson, A.M. \& Ydenberg, R.C. 2017. Long-term continental changes in wing length, but not bill length, of a long-distance migratory shorebird. Ecol. Evol. 7: 3243-3256.

Leal, M. \& Fleishman, L.J. 2002. Evidence for habitat partitioning based on adaptation to environmental light in a pair of sympatric lizard species. Proc. R. Soc. B269: 351-359.

Lindström, Å., Kvist, A., Piersma, T., Dekinga, A. \& Dietz, M.W. 2000. Avian pectoral muscle size rapidly tracks body mass changes during flight, fasting and fuelling. J. Exp. Biol. 203: 913-919.

Lindström, Å. \& Piersma, T. 1993. Mass change in migrating birds: the evidence for fat and protein storage re-examined. Ibis 135: 70-78.

Littleford-Colquhoun, B.L., Clemente, C., Thompson, G., Cristescu, R.H., Peterson, N., Strickland, K., Stuart-Fox, D. \& Frere, C.H. 2019. How sexual and natural selection shape sexual size dimorphism: evidence from multiple evolutionary scales. Funct. Ecol. 33: 1446-1458.

Lockwood, R., Swaddle, J.P. \& Rayner, J.M.V. 1998. Avian wingtip shape reconsidered: wingtip shape indices and morphological adaptations to migration. J. Avian Biol. 29: 273292.

Lofsvold, D. 1988. Quantitative genetics of morphological differentiation in Peromyscus. II. Analysis of selection and drift. Evolution 42: 54-67.

Lyon, B.E. \& Montgomerie, R. 2012. Sexual selection is a form of social selection. Philos. Trans. R. Soc. B 367: 22662273.

Marchetti, K. 1993. Dark habitats and bright birds illustrate the role of the environment in species divergence. Nature 362: 149-152. 
Mayr, E. 1954. Change of genetic environment and evolution. In Huxley, J.S., Hardy, A.C. \& Ford, E.B. (eds) Evolution as a Process: 157-180. London: Allen and Unwin.

McCloskey, J.T. \& Thompson, J.E. 2000. Sex-related differences in migration chronology and winter habitat use of Common Snipe. Wilson Bull 112: 143-148.

McCloskey, J.T., Thompson, J.E. \& Ballard, B.M. 2009. Diet composition of wintering Wilson's Snipe. Wilson J. Ornithol. 121: 434-439.

McEntee, J.P., Penalba, J.V., Werema, C., Mulungu, E., Mbilinyi, M., Moyer, D., Hansen, L., Fjeldsa, J. \& Bowie, R.C. 2016. Social selection parapatry in Afrotropical sunbirds. Evolution 70: 1307-1321.

Milá, B., Wayne, R.K. \& Smith, T.B. 2008. Ecomorphology of migratory and sedentary populations of the Yellow-rumped Warbler (Dendroica coronata). Condor 110: 335-344.

Miller, E.H. 1984. Communication in breeding shorebirds. In Burger, J. \& Olla, B.L. (eds) Shorebirds: Breeding Behavior and Populations: 169-241. New York, NY: Plenum.

Miller, E.H. 1996. Acoustic differentiation and speciation in shorebirds. In Kroodsma, D.E. \& Miller, E.H. (eds) Ecology and Evolution of Acoustic Communication in Birds: 241-257. Ithaca, NY: Comstock/Cornell University Press.

Minias, P., Kaczmarek, K., Wlodarczyk, R. \& Janiszewski, T. 2013. Wing shape influences stopover strategies in a migratory shorebird, the Common Snipe. Condor 115: 535-542.

Minias, P., Meissner, W., Włodarczyk, R., Ozarowska, A., Piasecka, A., Kaczmarek, K. \& Janiszewski, T. 2015. Wing shape and migration in shorebirds: a comparative study. Ibis 157: 528-535.

Minias, P., Surmacki, A., Kudelska, K., Podlaszczuk, P., Kamiński, M., Kaczmarek, K., Włodarczyk, R. \& Janiszewski, T. 2018. Variation in melanin pigmentation of a sexually selected plumage trait and its adaptive value in the Common Snipe Gallinago gallinago. Ibis 160: 101-111.

Mlíkovský, J. 2002. Cenozoic Birds of the World Part 1: Europe. Prague: Ninox Press.

Morales, H.E., Pavlova, A., Sunnucks, P., Major, R., Amos, N., Joseph, L., Wang, B., Lemmon, A.R., Endler, J.A. \& Delhey, K. 2017. Neutral and selective drivers of colour evolution in a widespread Australian passerine. J. Biogeogr. 44: 522-536.

Mutumi, G.L., Jacobs, D.S. \& Winker, H. 2017. The relative contribution of drift and selection to phenotypic divergence: a test case using the Horseshoe Bats Rhinolophus simulator and Rhinolophus swinnyi. Ecol. Evol. 7: 4299-4311.

Panhuis, T.M., Butlin, R., Zuk, M. \& Tregenza, T. 2001. Sexual selection and speciation. Trends Ecol. Evol. 16: 364-371.

Parmalee, P.W. \& Klippel, W.E. 1982. Evidence of a boreal avifauna in middle Tennessee during Late Pleistocene. Auk 99: 365-368.

Piersma, T., Davidson, N. \& Evans, P. 1984. Estimation of the protein reserves of waders: the use and misuse of standard muscle volume. Wader Study Group Bull. 42: 19-22.

Prater, A.J., Marchant, J.H. \& Vuorinen, J. 1977. Guide to the Identification and Ageing of Holarctic Waders. Thetford: British Trust for Ornithology.

Price, T. 2008. Speciation in Birds. Greenwood Village, CO: Roberts \& Company Publishers.
Price, J.J. 2019. Sex differences in song and plumage color do not evolve through sexual selection alone: new insights from recent research. J. Ornithol. 160: 1213-1219.

Pyle, P. 2008. Identification Guide to North American Birds. Part II: Anatidae to Alcidae. Point Reyes Station, CA: Slate Creek Press.

R Core Team 2019. R: A Language and Environment for Statistical Computing. Vienna: R Foundation for Statistical Computing.

Rayner, J.M.V. 1988. Form and function in avian flight. Curr. Ornithol. 5: 1-66.

Reddig, E. 1978. Der ausdrucksflug der Bekassine (Capella gallinago gallinago). J. Ornithol. 119: 357-387.

Rodrigues, T.M., Andrade, P., Rodrigues, M. \& Gonçalves, D. 2018. Mixed patterns of morphological adaptation to insularity in an aerial displaying bird, the Common Snipe Gallinago gallinago. Ibis 160: 870-881.

Rodrigues, T.M., Miller, E.H., Drovetski, S.V., Zink, R.M., Fjeldsa, J. \& Gonçalves, D. 2020. Phenotypic divergence in two sibling species of shorebird: common Snipe and Wilson's Snipe (Charadriiformes: Scolopacidae). Ibis. Dryad

Safran, R.J., Flaxman, S.M., Kopp, M., Irwin, D.E., Briggs, D., Evan, M.R., Funk, W.C., Gray, D.A., Hebet, E.A., Seddon, N., Scordato, E., Symes, L.B., Tobias, J.A., Toews, D.P.L. \& Uy, J.A.C. 2012. A robust new metric of phenotypic distance to estimate and compare multiple trait differences among populations. Curr. Zool. 58: 426-439.

Safran, R.J., Scordato, E.S.C., Symes, L.B., Rodríguez, R.L. \& Mendelson, T.C. 2013. Contributions of natural and sexual selection to the evolution of premating reproductive isolation: a research agenda. Trends Ecol. Evol. 28: 643650.

Seddon, N., Botero, C.A., Tobias, J.A., Dunn, P.O., MacGregor, H.E.A., Rubenstein, D.R., Uy, J.A.C., Weir, J.T., Whittingham, L.A. \& Safran, R.J. 2013. Sexual selection accelerates signal evolution during speciation in birds. Proc. R. Soc. B 280: 20131065.

Seebohm, H. 1888. The Geographical Distribution of the Family Charadriidae, or the Plovers, Sandpipers, Snipe, and Their Allies. Manchester: Henry Sotheran \& Company.

Seehausen, O., Terai, Y., Magalhaes, I.S., Carleton, K.L., Mrosso, H.D., Miyagi, R., van der Sluijs, I., Schneider, M.V., Maan, M.E., Tachida, H., Imai, H. \& Okada, N. 2008. Speciation through sensory drive in cichlid fish. Nature 455 : 620-626.

Servedio, M.R., Van Doorn, G.S., Kopp, M., Frame, A.M. \& Nosil, P. 2011. Magic traits in speciation: 'magic' but not rare? Trends Ecol. Evol. 26: 389-397.

Šidák, Z. 1967. Rectangular confidence regions for the means of multivariate normal distributions. J. Am. Stat. Assoc. 672: 626-633.

Spurgin, L.G., Illera, J.C., Jorgensen, T.H., Dawson, D.A. \& Richardson, D.S. 2014. Genetic and phenotypic divergence in an island bird: isolation by distance, by colonization or by adaptation. Mol. Ecol. 23: 1028-1039.

Stock, C. \& Harris, J.M. 1992. Rancho La Brea: A Record of Pleistocene Life in California. Los Angeles, CA: Natural History Museum of Los Angeles County Museum.

Sutton, G.M. 1981. On aerial and ground display of the World's snipes. Wilson Bull. 93: 457-609.

Székely, T., Freckleton, R.P. \& Reynolds, J.D. 2004. Sexual selection explains Rensch's rule of size 
dimorphism in shorebirds. Proc. Natl Acad. Sci. USA 101: 12224-12227.

Székely, T., Lislevand, T. \& Figuerola, J. 2007. Sexual size dimorphism in birds. In Fairbairn, D.J., Blanckenhorn, W.U. \& Székely, T. (eds) Sex, Size and Gender Roles: Evolutionary Studies of Sexual Size Dimorphism: 27-37. New York: Oxford University Press.

Székely, T., Reynolds, J.D. \& Figuerola, J. 2000. Sexual size dimorphism in shorebirds, gulls, and alcids: the influence of sexual and natural selection. Evolution 54: 1404-1413.

Thönen, W. 1969. Auffallender Unterschied zwischen den instrumentalen Balzlauten der europäischen und nordamerikanischen Bekassine Gallinago gallinago. Ornithol. Beobacht. 66: 6-13.

Tobias, J.A., Aben, J., Brumfield, R.T., Derryberry, E.P., Halfwerk, W., Slabbekoorn, H. \& Seddon, N. 2010. Song divergence by sensory drive in Amazonian birds. Evolution 64: 2820-2839.

Tobias, J.A., Montgomerie, R. \& Lyon, B.E. 2012. The evolution of female ornaments and weaponry: social selection, sexual selection and ecological competition. Philos. Trans. R. Soc. B 367: 2274-2293.

Trefry, S.A. \& Diamond, A.W. 2017. Exploring hypotheses for sexual size dimorphism in frigatebirds. Evol. Ecol. Res. 18: 225-252.

Tuck, L.M.1972. The Snipes: A Study of the Genus Capella. Ottawa: Canadian Wildlife Service Monograph Series 5.

Ura, T., Azuma, N., Hayama, S. \& Higashi, S. 2005. Sexual dimorphism of Latham's Snipe (Gallinago hardwickil). Emu 105: 259-262.

West-Eberhard, M.J. 1983. Sexual selection, social competition, and speciation. Q. Rev. Biol. 58: 155-183.

West-Eberhard, M.J. 2014. Darwin's forgotten idea: the social essence of sexual selection. Neurosci. Biobehav. Rev. 46: 501-508.

Wheeler, B. \& Torchiano, M. 2016. ImPerm: Permutation Tests for Linear Models. R package version 2.1.0.

Wiens, J.J., Ackerly, D.D., Allen, A.P., Anacker, B.L., Buckley, L.B., Cornell, H.V., Damschen, E.I., Jonathan Davies, T., Grytnes, J.A., Harrison, S.P., Hawkins, B.A., Holt, R.D., McCain, C.M. \& Stephens, P.R. 2010. Niche conservatism as an emerging principle in ecology and conservation biology. Ecol. Lett. 13: 1310-1324.

Wilkins, M.R., Karaardic, H., Vortman, Y., Parchman, T.L., Albrecht, T., Petrzelkova, A., Ozkan, L., Pap, P.L.,
Hubbard, J.K., Hund, A.K. \& Safran, R.J. 2016. Phenotypic differentiation is associated with divergent sexual selection among closely related Barn Swallow populations. J. Evol. Biol. 29: 2410-2421.

Wilkins, M.R., Seddon, N. \& Safran, R.J. 2013. Evolutionary divergence in acoustic signals: causes and consequences. Trends Ecol. Evol. 28: 156-166.

Winger, B.M. \& Bates, J.M. 2015. The tempo of trait divergence in geographic isolation: avian speciation across the Maranon Valley of Peru. Evolution 69: 772-787.

Wolak, M.E., Fairbairn, D.J. \& Paulsen, Y.R. 2012. Guidelines for estimating repeatability. Methods Ecol. Evol. 3: $129-137$.

Zink, R.M. 2014. Homage to Hutchinson, and the role of ecology in lineage divergence and speciation. J. Biogeogr. 41: 999-1006.

Zink, R.M., Rohwer, S., Andreev, A.V. \& Dittmann, D.L. 1995. Trans-Beringia comparisons of mitochondrial DNA differentiation in birds. Condor 97: 639-649.

Received 3 July 2019;

revision accepted 21 September 2020.

Associate Editor: Phil Battley.

\section{SUPPORTING INFORMATION}

Additional supporting information may be found online in the Supporting Information section at the end of the article.

Table S1. List of collections and specimens analysed for this study.

Table S2. Most measurements were highly repeatable.

Table S3. Little variance explained by the last principal components (PC) of principal components analyses (PCA) on residuals' variance-covariance matrices. PC scores of analyses of traits measured on skeletons and study skins of Common Snipe Gallinago gallinago and Wilson's Snipe G. delicata. 